\title{
Osmanlı Klasik Döneminde Vakıf Yapıların Korunmasında Onarım Aşamaları
}

\section{Repairing Processes of Protected Foundation Buildings in Classical Ottoman Era}

\section{Ibrahim YILMAZ}

Hisar Mimarlık, Bursa, Türkiye

\section{Özet}

Osmanlı döneminde, sosyal hizmetlerin yerine getirilebilmesi amacıyla vakıf kimliği altında çok sayıda mimari eser inşa edilmiştir. Bu eserler yapıldıkları dönemde ne kadar özenle tasarlanıp inşa edilseler de, zamanla tadilat ve onarımları gerekmiştir. Vakıf yapılarında ortaya çıkan tahribatların onarımı, kurum aracılığıyla sağlanan hizmetlerin kesintiye uğratılmadan sonsuza dek devam ettirilmesi amacını taşımaktadır. Bu bağlamda, Klasik dönemde vakıf yapıların korunması amacıyla geliştirilmiş ve onarım sonrası hesap verilebilirliğin temel alındığı bir onarım mekanizması bulunmaktaydı. Bu mekanizmada yapıların korunmasına yönelik hukuki ve dini kuralların varlığı kadar, onarım eylemlerinin organizasyonunda ve işleyişinde her türlü idari, teknik ve mali altyapının sağlandığı bir onarım süreç sisteminin bulunduğu görülmektedir.

Bu çalışmanın amacı, Osmanlı́nın Klasik dönemlerinde Türk mimarisinin temel taşlarını oluşturan vakıf yapıların, korunmasında ve günümüze ulaşmasında esas neden olan onarım etkinliklerinde kullanılan aşamalar ile aşamalarda yürütülen işlemlerin belirlenmesidir. Araştırmada onarımlarda izlenen süreçler, yönetim mekanizmaları, konuyla ilgili kurum ve kişilerin niteliklerine ilişkin arşiv belgelerinden elde edilen bilgilerle de desteklenerek aktarılmıştır.

Anahtar Kelimeler: Osmanlı dönemi, onarım, vakıf yapıları, onarım süreçleri, arşiv belgeleri.

\section{Abstract}

In Ottoman era, many architectural pieces of art under the identity of foundation were built with the purpose of fulfilling social services. Although these pieces of art were toroughly designed and constructed they required repairing within time. The repairing of the damage occurred in foundation buildingds aim to provide the continuity of the services provided by the foundation to last forever without fail. In this context there was a repairing mechanism in classical period which was developed with the aim of protecting foundation buildings and in which explanation after repair was taken as a basis. In this mechanism it is observed that there was an administrative, technical and financial support in the organizarion and processing of the repair works as well as the existence of legal and religiousrules.

The aim of this study is to determine the processes run in repair activities which constitute the reason how the foundation buildings (which constitute the foundation stones of Turkish architecture in classical era if Ottoman) were protected and preserved until today and the operations used in those processes. In the research, the stages followed in repairs, administrative mechanisms and the properties of people and authorities related with the subject sere conveyed with the support of information gathered form the archivr documents.

Key words: Ottoman era, repairing, foundation buildings, repair processes, archive documents 


\section{Giriş}

Türk mimarisinin temelini oluşturan vakıf yapıların ortaya çıkmasında vakıf kurumlarının etkisi büyük olmuştur. ${ }^{1}$ Osmanlı döneminde sosyal, ekonomik ve kültürel yaşamın önemli parçası olan vakıf yapıları, sultanlar başta olmak üzere hanedan üyeleri, devletin yüksek kademesindeki memurları ile varlıklı hayırsever vatandaşlar tarafından kurulan vakıflar aracılığıyla inşaa edilmekteydi. ${ }^{2}$ Bu şekilde vakıf kimliği altında gerçekleştirilen cami, medrese, imarethane, hamam, şifahane gibi yapılar, kamu yararı bulunan ve kamunun kullanımına açık eserlerdir. ${ }^{3}$ Diğer yandan, vakıf kurumunun hukuki, ekonomik, sosyal ve dini yönleri incelendiğinde, yapiların meydana getirilmesinde olduğu gibi, bu yapıların korunmasında da en önemli kaynağın vakıf kurumunun kendisi olduğu görülmektedir. Vakıf kimliği altında yatan temel kavram sonsuza dek hizmet etme anlayışıdır. ${ }^{4} \mathrm{Bu}$ durum, kurum aracılığıyla karşılanan toplumsal hizmetlerin sağlıklı bir şekilde yürümesi anlamına geldiği gibi vakfın kişiye, topluma ve devlete sağlamış olduğu maddi ve manevi faydalarının da sürekliliği anlamına gelmekteydi. Bu bağlamda, vakıf kurumu aracılığıyla yürütülen hizmetlerin kesintiye uğratılmadan devam ettirilmesinde gerekli olan önemli öğe, bu hizmetlerin yerine getirileceği vakıf yapılarının korunmasıdır. Bu nedenle, vakıf yapılarında kullanım süreci içerisinde değişik etkenlere bağlı olarak meydana gelen tahribatların onarımı, vakıf yapısının işlevsel sürekliliğinin devam ettirilmesi amacını taşımaktadır. ${ }^{5}$

Osmanlı klasik döneminde vakıf yapıların onarımları, vakıf tarafından ve vakfiyelerde belirlenmiş şartlara uygun, katılımcı onarım süreçleri kullanılarak gerçekleştirilmekteydi. ${ }^{6}$ Vakıf yapılarında onarım ihtiyacının ortaya çıkmasıyla birlikte, yapının onarılması ve sonrasında işlevini yeniden devam ettirmesi arasında geçen zamanda yürütülen aşamalar yasal, ekonomik ve idari işler bakımından oldukça zengin ve disiplinli bir görünüme sahiptir. Onarım faaliyetleri hazırlık, icra ve sonrası olmak üzere 3 aşamada gerçekleştirilmekteydi. Onarım faaliyetlerinde kullanılan bu aşamalar ile aşamalarda yürütülen işlemlerin, Osmanlı klasik çağları olarak adlandırılan 16. yüzyıldan başlayarak, 19. yüzyıl başlarına kadar geçen 300 yılı aşkın bir zamanda fazla değişikliğe uğramadan, adeta gelenekselleşmiş pratikler halinde devam ettirildiği arşiv belgelerinin verdiği bilgilerden anlaşılmaktadır. Ancak, klasik döneminin sona ermesiyle birlikte devlet, imar ve onarım faaliyetlerinde geleneksel yönetim anlayışını bırakarak batılılaşma etkisi altında yeniden yapılanma sürecine girmiştir. ${ }^{7}$ Vakıf

1 Ömür Bakırer, "Vakfiyelerde Binaların Tamiratı ile İlgili Şartlar ve Bunlara Uyulması" Vakıflar Dergisi, Vakıflar Genel Müdürlüğü Yayınları, S. X, Ankara, 1973, s. 113.

2 İbrahim Yılmaz, S.Ümit Dikmen, “Osmanlı Döneminde Yapıların Onarım ve Restorasyonunda Tasarım ve Onay Süreci" 23.Uluslararası Katılımlı Yapı EYaşam Kongresi, Mimarlar Odası Bursa Şubesi, Bursa, 2011, s. 169.

3 Yilmaz ve Dikmen, a.g.m., s. 169.

4 Tuba Akar, "Tanzimat Öncesinde Vakıf Kurumu ve Yapıların Korunması" Vakıflar Dergisi, Vakıflar Genel Müdürlüğü Yayınları, S. 33, Ankara, 2010, s. 90.

5 Akar, a.g.m., s. 92.

6 Yllmaz ve Dikmen, a.g.m., s. 170.

7 A. Şevki Duymaz, "II. Abdülhamit Dönemi İmar Faaliyetleri", Süleyman Demirel Üniversitesi Sosyal Bilimler Enstitüsü, Yayınlanmamış Doktora Tezi, Isparta, 2003, s.30. 
yapıların onarım işlerini bir merkezden yürütmek amacıyla, 1826 yılında kurulan Evkaf1 Hümayun Nezareti'nin bünyesinde, 1838 yılında Evkaf Tamirat Müdürlüğü kurulmuştur. ${ }^{8}$ Klasik dönemde bağımsız bütçeleri bulunan ve her biri ayrı bir tüzel kişiliğe sahip vakıfların gelirlerinin devlet hazinesine aktarılması ve bu gelirlerin kamu açıklarının kapatılmasında kullanılması sonucu harap olan vakıf yapıların onarımları için gereken para Evkaf Nezaretince karşılanamamıştır. ${ }^{9}$ Bu yüzden, Osmanlı'nın son dönemlerinde vakıf yapıların onarım ihtiyaçları giderilemez bir hale gelmiştir. ${ }^{10}$

Bu bağlamda Osmanlı klasik dönemi, onarımların vakıf sistemi koruma döngüsü içinde icra edildiği bir dönem olmuştur. Bu dönemde, vakıf yapılarında ortaya çıkan onarım ihtiyacı, klasik dönem sonrası merkezi uygulamaların aksine öncelikli olarak ele alınmış, onarımlar yerel ve özerk yapısıyla vakıf kurumu tarafından katılımcı onarım süreçleri kullanılarak yürütülmüştür.

Bu çalışmada, vakıf kurumunun Tanzimat öncesinde, yani vakıfların Evkaf Nezareti altında merkezi bir yapıya bağlanmadan önceki kurumsal yapısı içerisinde, vakıf yapılarının onarım çalışmalarında kullanılan aşamalar ile bu aşamalarda icra edilen işlemlerin belirlenmesi hedeflenmiştir. Çalışmanın kapsamı, vakıf yapı onarımlarının süreçler halinde yürütüldügü 16. yüzyıldan başlayarak 19. yüzyıl ilk yarısına kadar devam eden Osmanlı klasik dönemiyle sınırlı tutulmuştur. İncelenen dönemde, vakıf yapıların onarım etkinliklerinde kullanılan süreçlerin ve aşamaların belirlenmesinde, gerek yayınlanmış eserlerden elde edilen, gerekse bu makalede sunulan 16. yüzyıl, 17. yüzyıl ve 18. yüzyıllara ait mahkeme sicillerinden elde edilen arşiv belgelerinin verdiği bilgilerden yararlanılmıştır. Bu belgelerde, sözü edilen yüzyıllarda vakıf yapılarının onarım süreçlerinde yürütülen işlemler, yönetim sistemleri, onarım çalışmalarına katılan kurum ve kişilerin niteliklerine ilişkin bilgiler de bulunmaktadir.

\section{Onarımın Gerekliliği, Vakfiyelerde Onarım Şartları ve Rakabe}

Osmanlı devletinde onarım çalışmasının genel amacı yapıyı ayakta tutmak, yıkılan kısımları yeniden yaparak biçimsel bütünlüğü sağlamaktı. Kısaca bir tamir faaliyetiydi. Vakıf yapılarında onarım çalışmaları ise, tamir etkinliğinin yanında toplumsal hizmetlerin kesintiye uğratılmadan faaliyetlerin devam ettirilmesi amacını taşımaktadır. Bu bağlamda, kamu hizmetlerine yöneltilmiş olan vakıf kurumunun uzun yıllar hizmet edebilmesi, bu hizmetlerin yerine getirileceği vakıf yapılarının korunmasına, ortaya çıkan onarım ihtiyacının zamanında yapılan uygun müdahalelerle giderilmesine bağlı olmuştur. ${ }^{11}$ Ayrıca, vakıflar sultanlar, vezirler, yörenin örfi idarecileri tarafından kurulduğundan, inşa ettirdikleri yapıların her zaman bakımlı olması siyasi iradenin gücünün devamlılı̆̆ını da simgelemekteydi. ${ }^{12}$

8 Duymaz, a.g.t., s. 39.

9 Ertem, a.g.m., s. 48.

10 Ertem, a.g.m., s. 48.

${ }^{11}$ Halim Baki Kunter, “Türk Abidelerinin İdare, Muhafaza, Bakım ve Onarım Mevzuunda Tatbik Edilmiş Olan Esaslar" Uluslararası I. Türk Sanatları Kongresi, Ankara, 1959, s. 263

12 Amy Singer, Osmanlı'da Hayırseverlik Kudüs'te Bir Haseki Sultan Imareti, Çev. Dilek Şendil, Tarih Vakfı Yurt Yayınları, İstanbul, 2004, s. 86. 
Osmanlı döneminde kurulan vakıfların düzenlenen vakfiyelerinde, vakfın nitelik ve amacına, yönetim ve işleyiş şekline ait esaslar arasında vakıf gelirlerinin öncelikli olarak vakıf binalarının bakım ve onarımı için ayrılmasını öngören kurucu hükümleri bulunmaktadır. ${ }^{13} 14$. yüzyıl Osmanlı döneminde kurulan vakıfların onarımla ve onarım personelinin istihdamı ile ilgili olarak vakfiyelerde yer alan şartlarda, onarım konusunun genel bir tutumla ele alınmış olduğu görülmektedir. ${ }^{14}$ Tamirata harcanacak para miktarı ve bu konuda çalışacakların sayısı ve maaşları belirtilmemiştir. Ancak bu dönem vakfiyelerinde, onarım masraflarını karşılamak için vakfedilen akarlardan gelen gelirlerin öncelikle hangi yerlerin tamirine harcanacağı açıkça belirtilmiştir. ${ }^{15} 1385$ tarihinde Sultan I. Murat Vakfı için hazırlanan vakfiyede, vakfedilen mülkler ayrıntılı biçimde anlatıldıktan sonra, vakıf akarlarından elde edilecek gelirlerin öncelikle imaretin tamirine harcanmasını şart koşan vakıf kurucusunun hükmü bulunmaktadır. ${ }^{16}$ 15. yüzyıldan itibaren düzenlenen vakfiyelerde ise, onarım konusunun daha detaylı vurgulandığı, genel şartların yanı sıra gelirlerden tamirler için ne kadar para ayrılacağı, çalışacak personel ve alacağı maaşlar konusunda detaylı bilgiler verilmeye başlandığ görülmüştür. ${ }^{17} \mathrm{Bu}$ dönemde özellikle sultan vakfiyelerinde, vakıf görevlileri arasında onarım işlerinde görevlendirilecek vakıf görevlileri arasında onarım işlerinde görevlendirilecek vakıf mimarlarının sayıları ve ücretleri de açıkça belirtilmiştir. 1419 tarihinde Çelebi Sultan Mehmed tarafından kurulan Yeşil Külliye'nin vakfiyesinde, vakıf gelirlerinden günde 20 dirhem paranın onarım ve bakım masrafları için biriktirileceği belirtildikten sonra, vakıf görevlileri arasında onarım hizmetleri için iki mimarın bulunacağı ve her birine günde ikişer dirhem ücret ve ayda birer müd ${ }^{18}$ buğday verileceği belirtilmiştir. ${ }^{19} 1522$ tarihinde Kanuni Sultan Süleyman'ın annesi Hafse Sultan'ın Manisa'da imaret, cami, medrese, hankâh ve sıbyan mektebi için kurduğu vakfın hazırlanan vakfiyesinde, medrese, imaret ve zaviyede tamire muhtaç yerleri tamir etmek için mimari ilmine vâkıf bir mimarın bulunacağı ve günde üç dirhem ücret alacağ belirtilmiştir. $^{20}$

Diğer yandan, onarım çalışmaları öncelikli olarak vakfın kendi gelirleriyle, vakfın parası olmadığı durumlarda devlet hazinesinden sağlanan kaynaklarla gerçekleştirilmekteydi. Ancak, vakfın gelirlerinin yeterli olmadığ 1 durumlarda, onarım sürecinde vakıfta çalışan bütün personelin alacakları bir süre askıya alınmakta idi ki, bu

${ }_{13}$ Mefail Hızlı, “Osmanlı Vakıf Eserlerinin İnşa, Tamir ve Restorasyonları”, Uludağ Üniversitesi İlahiyat Fakültesi Dergisi, C. 5, S. 5, Bursa, 1993, s. 222.

${ }^{14}$ Emre Madran, "Osmanlı Devletinde Eski Eser Ve Onarım Üzerine Gözlemler" Belleten, TTK Yayını, C. XLIX, S. 195, Ankara, 1985, s. 520.

15 Bakırer, a.g.m., s. 115.

${ }_{16}$ Hasan Basri Öcalan, Sezai Sevim, Doğan Yavaş, Bursa Vakfiyeleri 1, Bursa Belediyesi Kültür A.Ş Yayınları, C. 1, Bursa, 2013, s. 158.

17 Bakırer, a.g.m., s. 116.

${ }^{18}$ Hububat ve bakliyat gibi kuru besinlerin ölçümünde kullanılan ölçü birimi. İki avucun aldığı tahil miktarıdır.

19 Öcalan, Sevim, Yavaş, a.g.e., s. 301.

20 İbrahim Hakkı Konyalı, “Kanuni Sultan Süleyman'ın Annesi Hafse Sultan'ın Vakfiyesi ve Manisa'daki Hayır Eserleri" Vakıflar Dergisi, Vakıflar Genel Müdürlüğü Yayınları, Ankara, 1969, S. VIII, s.49. 
sisteme rakabe denilmektedir. ${ }^{21}$ Rakabede onarım giderleri görevlilere ödenecek ücretlerden önce gelmektedir, mütevelli bunun aksine bir harcama yaparsa, bu tutarı kendisi ödemekle yükümlü kılınmıştır. ${ }^{22}$ Rakabe sisteminin uygulanabilmesi için, Divan-1 Hümayun'dan iki ayrı onay kararı alınması gerekmektedir. ${ }^{23} 1576$ tarihinde Bursa'da bulunan Kazzazoğlu vakfının mütevellisi mahkemeye yaptığı müracaatta, medresenin ve medreseye bitişik olan dükkanların onarıma ihtiyacı bulunduğunu belirterek müşâhade edilmesini mahkemeden talep etmiştir. ${ }^{24}$ Bunun üzerine mahkeme tarafından kurulan heyetin yerinde yaptığı inceleme sonucu, onarımın 17.000 akçeye mal olacağını tespit etmiştir. ${ }^{25}$ Ancak, vakfın hesapları incelendiğinde onarım için yeterli parası olmadığı tespit edilerek, bir buçuk yıl rakabe olmak kaydıyla onarım kararı verilmiştir. ${ }^{26}$ Heyetin rakabe kararı ve keşif raporları kadı tarafından Divan-1 Hümayun'a gönderildikten sonra, buradan gelen iki ayrı onay kararı ile onarım ve rakabe uygulamaları yürürlüğe girmiştir. ${ }^{27}$

\section{Onarım Süreçleri}

Bütün yapılar tamamlandıktan ve kullanılmaya başlanmasından itibaren yıpranmaya başlarlar ve iyi durumda kalabilmeleri, uzun süre yaşayabilmeleri için sürekli bakım ve onarıma ihtiyaç duyarlar. ${ }^{28} \mathrm{Bu}$ bağlamda, yapılarda onarım süreci onarım ihtiyacının ortaya çıkmasıyla birlikte başlamaktadır. Osmanlı döneminde vakıf yapılarında onarım ihtiyacı genel olarak zamanın ve kullanımın etkisiyle ortaya çıkan aşınmalar, bakımsızlık, deprem, sel ve yıldırım düşmesi gibi doğa olayları, yangınlar, savaşlar, toplumsal olaylar ve insan eliyle verilen hasarlar sonucu ortaya çlkmaktayd..$^{29}$ Vakıf yapıların korunması için genellikle sürekli ve belirli periyotlarla bakım usulü benimsenmiştir. ${ }^{30}$ Böylece, büyük yapısal sorunlar çıkması önceden önlenmekte, kullanım kapasitesi en üst düzeyde tutulmaktayd1. ${ }^{31}$ Buna eşit olarak, esaslı ve büyük onarımlara ancak doğal afetlerden ya da yangınlar ve savaşlardan sonra ihtiyaç duyulmaktaydı. ${ }^{32}$ Vakıf yapıların yaşam döngüsünde, kullanım süreci içerisinde meydana gelen tahribatların giderilmesi için yapılan onarım çalışmaları, yapının kullanımını belirli bir süre kısmen de olsa kesintiye uğratmaktadır. Klasik Osmanlı döneminde, vakıf yapıların korunmasına yönelik yürütülen onarım etkinliklerinde,

${ }^{21}$ Mefail Hızlı, "Osmanlı Vakıf Sisteminde Rakabe”, Uludă̆ Üniversitesi İlahiyat Fakültesi Dergisi, C. 6, S. 6, Bursa, 1994, s. 56.

22 Ömer Hilmi Efendi, İthaf-ül-Ahlâffi Ahkâm-il-Evkaf, Vakıflar Genel Müdürlüğü Yayınları, Ankara, 1977, s. 411.

${ }^{23}$ Hizlı, Rakabe, s. 59.

${ }^{24}$ Hizlı, Rakabe, s. 57.

${ }^{25}$ Hizlı, Rakabe, s. 57.

${ }^{26}$ Hizlı, Rakabe, s. 58.

27 Hizlı, Rakabe, s. 58.

28 A.Tanju Gültekin, Yapım Öncesi Süreç, Palme Yayıncllık, Ankara, 2007, S. 447, s. 34.

${ }^{29}$ Yllmaz ve Dikmen, a.g.m., $\quad$ s. 170.

30 Madran, Eski Eser ve Onarm, s. 543.

31 Madran, Eski Eser ve Onarrm, s. 543.

32 Madran, Eski Eser ve Onarım, s.543. 
günümüzde kullanılan proje yönetimi döngüsüne benzer, alt sistemlerden oluşmuş bir onarım döngü sisteminin bulunduğu görülmektedir. Onarım döngüsünde bulunan alt sistemler birbirini takip eden süreçler haline getirilerek onarım gerçekleştirilmekteydi. Bu bağlamda, klasik çağlarda vakıf yapılarında onarım ihtiyacının ortaya çıkması ile başlayıp, yapının onarılarak onarım sonrası kullanılır hale gelmesine kadar geçen sürede gerçekleşen onarım çalışmalarında üç temel alt sistem aşamasının bulunduğu arşiv belgelerinin verdiği bilgilerden anlaşılmaktadır. Bu aşamalar, ön hazırlık ve planlamaların yapıldığı, gerektiğinde onarım projelerinin de hazırlanarak onarım kararının alındığı onarım öncesi süreç, yapımın gerçekleştirildiği onarım süreci ve inşaat sonrası kesin kabul yapılarak onarımın aklandığı, bunun sonucunda yeniden kullanımın sağlandığı onarım sonrası süreçlerdir (Çizim 1).

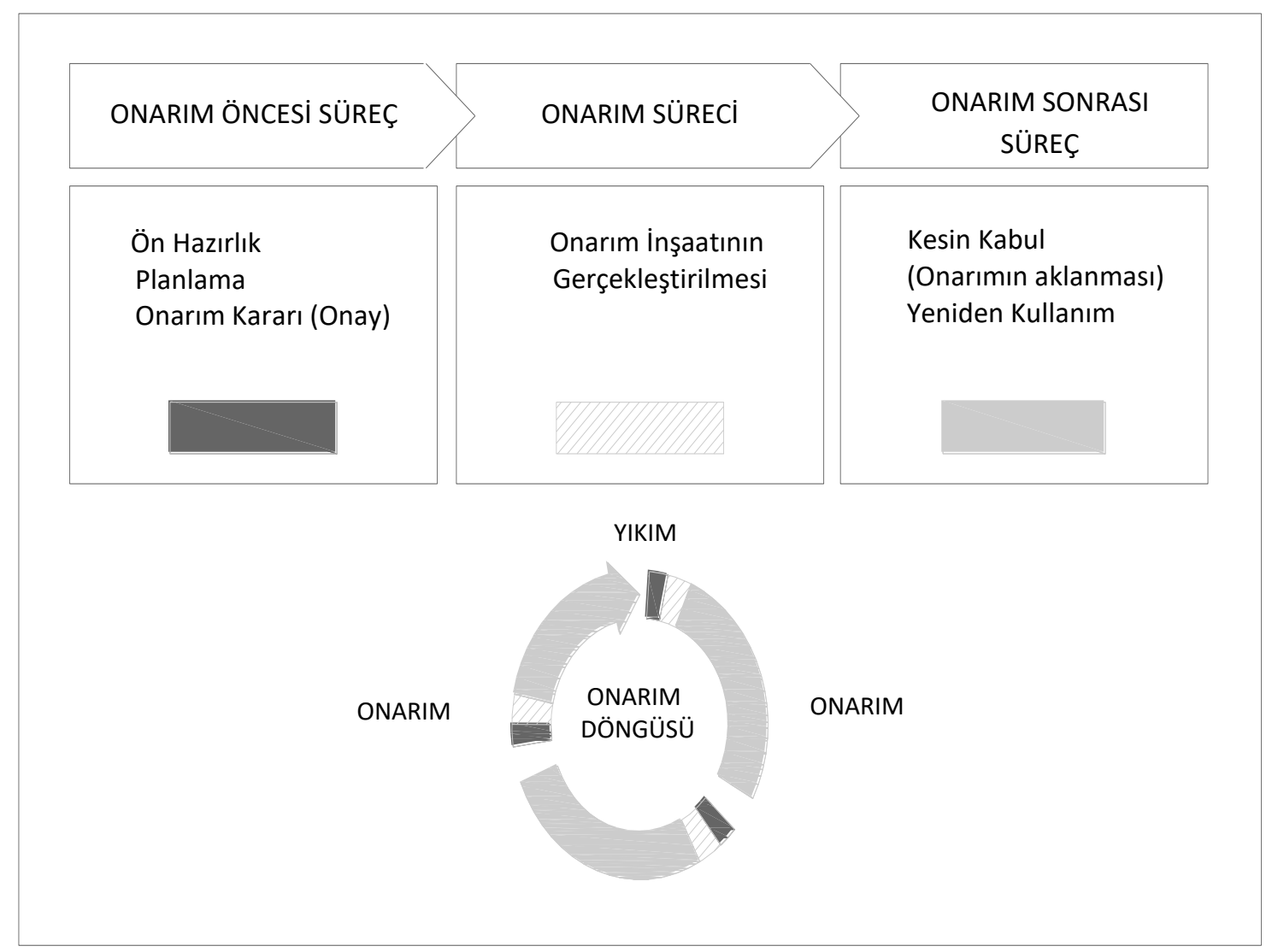

Çizim 1. Osmanlı döneminde vakıf yapıların onarımlarında kullanılan süreçler 


\subsection{Onarım Öncesi Süreç}

Klasik Osmanlı döneminde, vakıf yapıların onarım çalışmalarında onarım öncesi Divan-1 Hümayundan onay alınması gerekmektedir. ${ }^{33}$ Onarım öncesi süreç, vakfın mütevellisi ya da diğer görevlileri tarafından mahkemeye yapılan resmi talep ile bu talebin değerlendirilmesi sürecidir. ${ }^{34} \mathrm{Bu}$ süreçte yapının onarıma ihtiyacı olduğu belirtilir, yerinde incelenerek onarıma izin verilmesi mahkemeden talep edilirdi. Yapılan bu talebe karşılık, o yörenin mahkemesi tarafından kurulan heyetin hazırladığı keşif ve raporlar Divan-1 Hümayuna iletilmektedir. ${ }^{35}$ Divan'da görüşülerek alınan onarım kararı öncelikli olarak o yörenin kadısına gönderilmektedir. Nihai karar mercii olan Divan-1 Hümayundan gelen onarım kararının kadı tarafından vakfın mütevellisine iletilmesiyle birlikte onarım öncesi süreç sona ermektedir. Bu nedenle onarım öncesi süreci, aynı zamanda onarımın onay süreci olarak değerlendirmek mümkündür. Divan-1 Hümayun tarafından verilen onay kararlarında en önemli kriter, onarımın tahmini maliyetlerinin önceden belirlenmesidir. ${ }^{36}$ Bunun nedeni, onarımla ilgili yapı faaliyetlerinde ortaya çıkabilecek olası suiistimallerin önüne geçilmesi olduğu gibi maliyete ilişkin planlamalarda kontrol imkanı sağlanarak onarımın garanti altına alınmasıdır. Bu amaçla, mahkeme tarafından kurulan keşif heyetinde öncelikli olarak kadı adına bir naip, hassa mimarı, "ehl-i hibre üstâdlar", "ehl-i vukuf kimseler" ve inşaat işlerinden anlayan bigarez Müslümanlar bulunmaktaydı. ${ }^{37}$ Onarımı yapılacak binayı yerinde inceleyen heyet, öncelikli olarak binanın nerelerinin onarıma ihtiyaç duyduğunu, onarımda ne tür malzemelerin kullanılacağını, ne kadar işçilik ve nakliye gerektiğini tespit ederek, yerinde çıkarttığı onarım metrajlarını günün cari fiyatları ile çarparak onarımın yaklaşık maliyetini belirlemekteydi. ${ }^{38}$ Daha sonra, heyet tarafından hazırlanan bu keşif ve raporlar çok sayıda şahidin takip ettiği bir oturumda yörenin mahkemesi tarafından tescil edilirdi. ${ }^{39}$

Bu bağlamda, Klasik Osmanlı döneminde onarım etkinliklerinin en önemli aşamasını oluşturan onarım öncesi onay sürecinde yürütülen tüm çalışmaları yedi aşamaya ayırmak mümkündür. Bu aşamalar onarım öncesi süreçte onarım izni için kullanılan tüm işlemleri oluşturmaktadır. Bu süreçte yürütülen işlemler, işlemlerin gerektirdiği hiyerarşik düzen ve işlemlerde görev alanların yatay ve düşey eksenlerde oluşturdukları ilişkiler ağı, Osmanlı arşiv belgelerinden elde edilen bilgilerin de ışı̆̆ında süreç şeması halinde Çizim 2' de sunulmuştur.

33 Günümüze ulaşmış vakıf yapıları korunması gerekli kültür varlıkları olarak değerlendirilmektedir. $\mathrm{Bu}$ nedenle, bu yapıların günümüzdeki onarımları, Kültür Bakanlığı'na bağlı "Kültür Varlıklarını Koruma Bölge Kurulları" tarafından verilen onarım onay kararları ile gerçekleştirilmektedir.

34 Yilmaz ve Dikmen, a.g.m., s. 170.

35 Yllmaz ve Dikmen, a.g.m., s. 170.

36 Yilmaz ve Dikmen, a.g.m., s. 170.

37 Hizlı, İnşa, Tamir ve Restorasyonlar, s.229.

38 Yilmaz ve Dikmen, a.g.m., s. 171

39 Hızlı, İnşa, Tamir ve Restorasyonlar, s.229. 


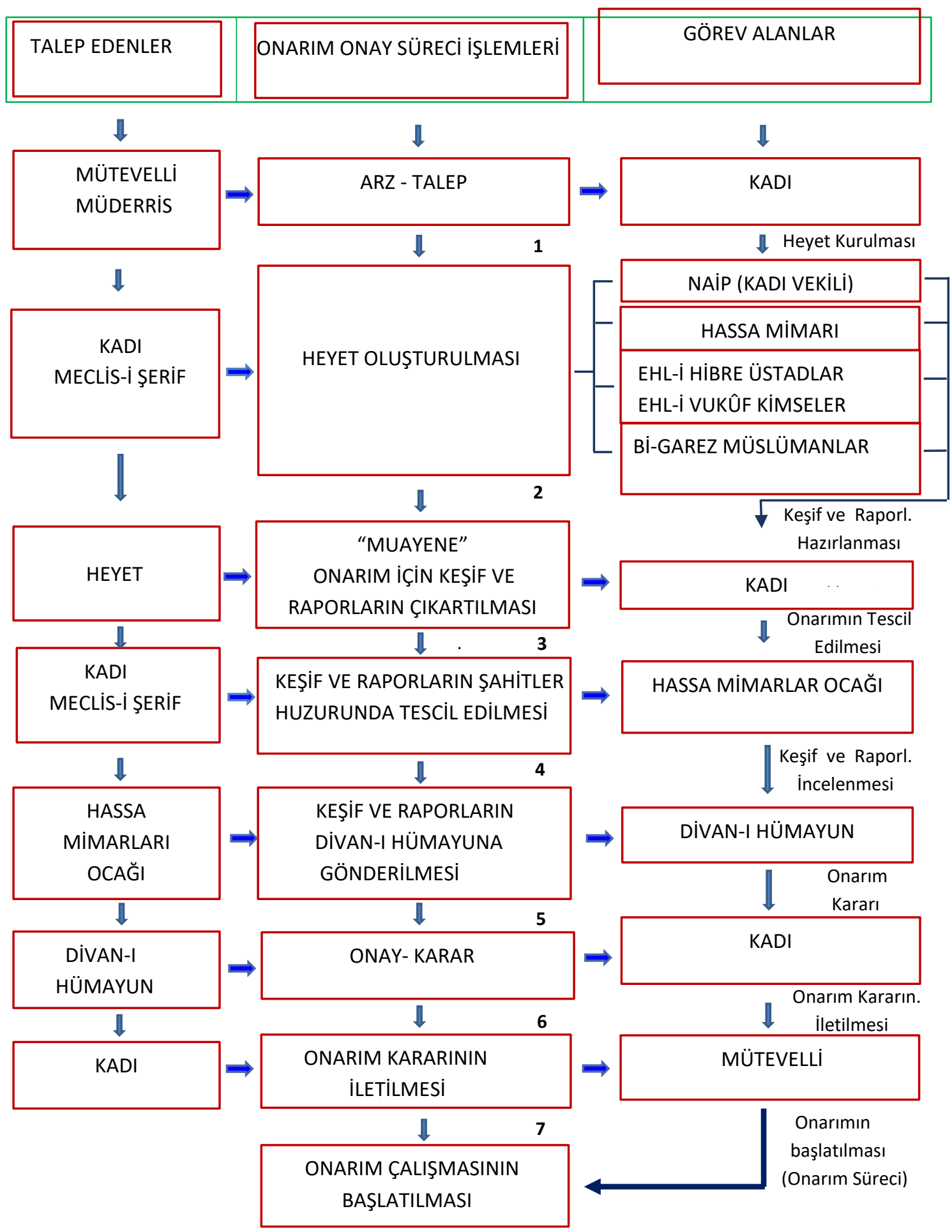

Çizim 2. Klasik Osmanlı döneminde vakıf yapılarında onarım öncesi onay süreç şeması. Çizim 2'de sunulan onarım öncesi onay süreci şemasına göre çıkartılan işlem aşamaları aşağıda açıklanmıştır. 
1. Arz ve Talep: Onarımına ihtiyaç duyulan vakıf yapısının bağlı bulunduğu vakfın mütevellisi, vakfın nazırı, bazen müderrisi ya da diğer mürtezikası, yapının bulunduğu yöredeki mahkemeye müracaat ederek yapılarının "harabe-müşrif" olduğunu, ciddi şekilde onarıma ihtiyacı bulunduğunu belirterek, kontrol ve keşif yapılmasını talep etmektedirler..$^{40}$ Mahkemeye yapılan bu talep doğrultusunda, kadı tarafından onarım öncesi sürecin resmi işlemleri başlatılmaktadır. ${ }^{41} 1572$ yılında Çelebi Sultan Mehmet vakıfları arasında yer alan Yeşil Cami ile medresenin "harabe-müşrif" olduğunu, vakfın imaretinde mütevelli olan Mustafa mahkemeye gelerek söylemiş, onarım amacıyla keşif yapılması için talepte bulunmuştur. ${ }^{42}$ Aynı şekilde, 1649 yılında Yıldırım Bayezid vakfı mütevellisi Rıdvan Ağa İbn-i Abdülmennan mahkemeye müracaat ederek, vakfın kapsamında bulunan cami, türbe, medrese ve bimarhanenin bazı bölümlerinin "harabemüşrif" olduğundan onarıma ihtiyaç duyulduğunu, binaların yerinde incelenerek onarım için keşif yapılmasını mahkemeden talep etmiştir. ${ }^{43}$ Ayrıca, vakfın yeterli parası bulunmadığı durumlarda, onarım masraflarını kendisi karşılayacağını belirtilerek keşif yapılmasını talep edenler de bulunmaktaydı. Bu konuda elde edilen bir arşiv belgesine göre, 1584 yılı Ekim ayı başlarında, Bursa' da bulunan Sultan Bayezid Vakfı'na ait Pirinç Hanın içinde "harabe-müşrif" durumda bulunan mescidin onarılması için, yöreden elHac Halil mahkemeye yaptığı müracaatta onarım masraflarını kendisi karşılayacağını belirtmiş, mescidin yerinde incelenerek keşfinin yapılmasını keşif nâibi Osman bin Ahmed'den talep etmiştir (Belge 1). ${ }^{44}$

$40 \quad$ Yilmaz ve Dikmen, a.g.m., s. 170.

41 Yilmaz ve Dikmen, a.g.m., s. 171.

42 Hizlı, Inşa, Tamir ve Restorasyonlar, s.227.

43 Hizlı, Inşa, Tamir ve Restorasyonlar, s.227.

44 Fahru'l-mu'teberīn el-Hāc Halīl ibn-i el-Hāc İvaz nām hoca meclis-i şer'-i şerīfde takrīr-i kelām idüb Mahrūse-i Brūsa'da merhūm ve mağfūrun leh Sultan Bayezid Hān tābe serah hazretlerinin binā eylediği hān-1 cedīd-i evvelin içinde olan mescid-i şerīfi cemāate kifāyet itmedüği bāisden bundan akdem fevt olan Hoca Mīrek nām kimesne mescid-i mezbūra muttasıl binā eyledüği mescid hālen harâbe-i müşrif olub tekrar yeniden binā olunmağa muhtāc olmağın ibtigā ellivecillehi kendü malımdan binā idüb ve cānib-i vakfa andan on beş akçe mukāta'a tayin itmek murādımdır kıbel-i şer'den üzerine varılub keşf olunmasın taleb iderin didükde kıbel-i şer'den Mevlānā Osman bin Ahmed ve zeyl-i kitābda isimleri mestūr olan cemāat ile üzerine varılub görüldükde fī'l-vāki' mescid-i sānīnin mihrabı ve sakfı ve kıble cānibinde olan dıvarları harāb olub harāb oldığına bāis nedir deyū suāl olundukda hān-1 mezbūrun emīni olan Mehmed Çelebi ibn-i Hasan Halife ve cemāat-i mezbūre haber virüb mescid-i mezkūrun harābe-müşrif olması vakfı olmadığındandır şöyle ki el-Hāc Halīlü'l-mezbūr mescid-i kadīme müsāvī kendü malından binā idüb ve kendüye birkaç mahzen īcād idüb yeddlerīçün cānib-i vakfa ayda on beş akçe mukāta' a takdīr olunub andan hāsıl olan rub'u mescid-i mezbūrun mesārifine vakf u ilhāk eyleye her vechile hayr-ı azīm vāki' olunmasını murād itdiklerinden merkūm el-Hāc Halīl dahī üslūb-1 mezbūr üzere binā eylemesine āzim ve müteahhid olmağın işbu hurūf ketb ü tahrīr olunub yedine def olundı ki vakt-i hācetde ashâbı idine tahrīren fī evāil-i Şevvāli'l-Mükerrem sene isnā ve tis'īne ve tis'a mi'e (1584 Ekim ayı başları) Şuhūdü'1-.hāl; Mevlānā Osman ibn-i Ahmed, el- 
2. Heyet Oluşturulması: Vakıf yapısının "harâbe-i müşrif" olduğu, onarıma ihtiyacı bulunduğu belirtilerek onarım için keşif ve müşahede edilmesi talebi mahkemeye bildirildikten sonra, onarılacak yapının yerinde incelenmesi ve onarım keşfinin çıkartılması amacıyla bir heyet kurulmaktadır. Heyet kadı tarafından oluşturulup onaylanmak durumundadır. ${ }^{45}$ Heyette mahkeme adına kadıyı temsilen "naip" ve hassa mimarlarından bir mimar, "ehl-i hibre üstadlar", "ehl-i vukuf kimseler" ile bina işlerinden anlayan "bi-garez Müslümanlar" bulunmaktayd1. ${ }^{46}$ Heyette hassa mimarlarından bir mimarın bulunması, mütevelli tarafından gerçekleştirilecek onarım işlerinde olası suiistimallerin önüne geçilmesi için benimsenmiştir. ${ }^{47} 15$ Aralık 1567 tarihinde, Bursa Ulucami'nin mütevellîsi Hacı Sinan bin Ali, caminin çatısının kurşunları, camları ve pencerelerinin, ayrıca vakfa ait hamamın, dükkânların ve su yolunun tamire ihtiyacı bulunduğunu belirterek keşif ve müşahede yapılması amacıyla yapının yerinde kontrol edilmesini mahkemeden talep etmiştir. Bunun üzerine kadı Mevlânâ Habîb Halîfe tarafından, erbâb-1 vukufdan Üstâd Ahmed bin Dâvud, el-Mi'mâr ve bazı bî-garez müslümanlardan oluşan bir heyet kurulmuştur (Belge 2). ${ }^{48} 1732$ yılında Orhangazi vakıflarından cami, medrese ve türbenin onarımları için, keşif ve müşahede olunması talebiyle vakıf mütevellisi Hacı Ali Ağa İbn Ahmet tarafından mahkemeye yapılan müracaat üzerine, kadı tarafından hassa mimarlarından Yakubzade Seyyid Said efendi ve halifesi Mehmed bin Mustafa ve bina işlerinden anlayan bi-garez müslümanlardan oluşan bir heyet kurulmuştur. ${ }^{49} 1761$ yılında Çelebi Sultan Mehmet Vakfına ait, cami, türbe ve medresenin kubbeleri ve sair kârgirlerinin onarımı için mahkemeye yapılan keşif talebine karşılık, Bursa Kadısı tarafından vekil olarak naip esSeyyid Ali Efendi ile hassa mimarı ve hülefası ve sair ebniye-i sukûf ahvaline vakıf olan bi-garez müslümanlardan ve ehl-i hibre üstadlardan oluşan bir heyet kurulmuştur. ${ }^{50}$

3. Onarım tespitinin yapılması ve keşfin çıkartılması; Onarım öncesi onay sürecinin en önemli aşaması, onarılacak yapının yerinde tespit edilerek onarım keşfinin çıkartılmasıdır. Bu amaçla, onarım talebine istinaden mahkeme tarafından kurulan

Mülāzım es-Seyyid Ömer ibn-i es-Seyyid Şa'ban, Hoca Yahşī ibn-i Durmuş Selim bin Ahmed, elHac Ramazan ibn-i Yusuf, El-Hāc Ca'fer ibn-i Mustafa ve gayruhum. B.K.S. B-129, s. 139.

${ }^{45}$ Madran, Eski Eser ve Onarm, s.527.

${ }^{46}$ Y.lmaz ve Dikmen, a.g.m., s. 171.

47 Şerafettin Turan, "Osmanlı Teşkilâtında Hassa Mimarları" Tarih Araştırmaları Dergisi 1, Ankara, 1963, s. 170.

48 “Oldur ki; Mahrûse-i Brusa'da câmi-i şerîf-i kebîrin hâlen mütevellîsi olan halefü'l-a'yân Hac1 Sinan bin Ali meclis-i şer'-i şerîfe hâzır olub câmi-i şerîfin sakfının kurşunı ve camları ve pencereleri ve evkafından hamam ve dekâkîn ve mecrâ-yı mâ tamâm termîm ve tamîre muhtâcdır hâlen görünmesin taleb iderim deyücek kıbel-i şer'den Mevlânâ Habîb Halîfe ve erbâb-1 vukufdan Üstâd Ahmed bin Dâvud el-Mi'mâr ve bazı bî-garez Müslümanlar irsâl olunub görüldükde fi'l-vâkı' zikrolınan yerlerin tamâm termîm ve ta'mîre muhtâc yerlerin olduğu mukarrer olub tahmîn-i sahîh ile tahmîn olundukda cem'an yigirmi yedi bin beş yüz akçe masraf vefâ eyleyüb hâlen termîm ve ta'mîri mühim ve lâzımdır deyû haber virdiklerinde mâ vaka'a bi't-taleb". B.K.S. A-94, s. 36.

${ }^{49}$ Hızlı, İnşa, Tamir ve Restorasyonlar, s. 228.

50 Muzaffer Erdoğan, "Osmanlı Devrinde Anadolu Camilerinde Restorasyon Faaliyetleri" Vakıflar

Dergisi, Vakıflar Genel Müdürlüğü Yayınları, Ankara 1968, s. VII, s. 197. 
heyet, yerinde yaptığı incelemelerde binanın nerelerinin onarıma ihtiyacı bulunduğunu, bunun için ne tür malzemelerin kullanılacağını, malzeme miktarlarını ve piyasada geçerli cari fiyatlarını, onarımın ne kadar usta, neccar ve diğer çalışanlarla yapılabileceğini kalem kalem yazarak onarımın yaklaşık maliyetini içeren keşif ve onarım raporlarını hazırlayarak bunu mahkemenin görüşüne sunarlardı. ${ }^{51}$ Vakıf yapıların onarımlarında, yapım öncesi hazırlanan keşiflerde asıl amaç, onarımın yaklaşık maliyetinin önceden belirlenmesidir. Bunun nedeni, onarımla ilgili yap1 faaliyetlerinde ortaya çıabilecek olası suiistimallerin önüne geçilmesi olduğu gibi, onarımın gerektirdiği parasal kaynakların nereden ve nasıl sağlanacağının önceden belirlenerek yatırımın garanti altına alınmasıdır. Bu sayede de yapım öncesi süreçte, özellikle maliyete ilişkin işlemlerde planlanma ve kontrol olanağı sağlanarak, yapım sonrası hesap verilebilirliğin sağlanmasıdır. 1552 tarihinde, Yeşil Cami'nin yapıldı̆̆ı günden beri tam 132 yıldır hiç yenilenmeyen kubbe kurşunlarının yenilenmesi gerektiği talep edilmiş, bu talebe karşılık hassa mimarı, ehl-i vukuf ve bi- garez müslümanlardan oluşan heyetin yerinde yaptığ1 incelemede onarımın10.000 akçeye çıkacağ1 keşif olunmuştur. ${ }^{52} 15$ Aralık 1567 tarihinde, Bursa Ulucami'nin çatı kurşunları ile cam ve çerçevelerinin, vakfa ait hamam, dükkanlar ve su yolunun tamiri için, hassa mimarı ve ehl-i vukûf ile yapılan keşifte, onarımın yaklaşık maliyetinin 27500 akçe olacağ hesaplanmıştır. ${ }^{53} 13$ Aralık 1677 tarihli diğer bir arşiv belgesine göre, Sultan Bâyezid vakıflarından Pirinç Han'ın mütevelli vekili Mustafa Efendi mahkemeye gelerek, hana ait odaların döşeme tuğlalarının, odalarda bulunan ocakların, ayrıca tahta keniflerin, merdivenin, ahırın kemer ayakları ve han ana giriş kapısı çatısının harap olduğunu ve onarıma ihtiyacı bulunduğunu belirtmiş, yapının yerinde kontrol edilerek yaklaşık maliyetinin çıartılması amacıyla keşif yapılmasını talep etmiştir. Bunun üzerine mahkemeden sorumlu kadı Mevlânâ Mustafa Efendi tarafından, hâssa mi'mârı kaim-i makāmı olan el-Hâc Mustafa ibn-i Abdullah ile ehl-i hibre üstadlar", "ehl-i vukuf kimseler" ile bina işlerinden anlayan bî̀-garez müslümanlardan oluşan bir heyet kurulmuştur. Heyetin yerinde yaptığı incelemede, yapılacak olan imalatlar ve onarım miktarları tek tek belirlenmiştir. Belirlenen onarım miktarları günün cari fiyatları ile çarpılarak yapılan hesaplamada onarımın yaklaşık maliyetinin bir yük 13350 akçe $\mathrm{e}^{54}$ olacağ 1 tespit edilmiştir (Belge 3). ${ }^{55}$ Pirinç Han'ında 13 Aralık 1677 tarihinde yapılacak

51 Yilmaz ve Dikmen, a.g.m., s. 171.

52 Doğan Yavaş, "Bursa Yeşil Cami'de Yapılan Onarımlar" XIV. Ortaçă̆ ve Türk Dönemi Kazıları Ve Sanat Tarihi Araştırmaları Sempozyumu, Konya, 2011, s. 632.

53 B.K.S. A-94, s. 36. Heyet oluşturulması bölümünde sunulan Belge 2' de belirtilmektedir.

54 Bir yük 100000 akçedir. Buna göre onarım maliyeti 113350 akçedir.

55 Dâru's-saltanati'l-aliyye-i Kostantıniyye'de âsûde olan cennetmekân firdevs-âş̧iyân merhûm ve mağfûrun leh Sultan Bâyezid Hân tâbe serah hazretlerinin imaret-i âmireleri evkāfından olup mahrûse-i Burûsa'da vâkı' Pirinç Hanı dimekle ma'rûf hanının nâzırı ve evkāf-ı mezbûr mütevellîsinin tarafından vekîl-i müsecceli olan mefharu'l-hutabâ Mustafa Efendi ibnü'1 Merhûm Mehmed Efendi meclis-i şer'de takrîr-i kelâm ve bast-1 merâm idüp hân-1 merkûmda vâkı' odaların müste' cirleri olan işbu hâzirûn-1 bi'l-meclis el-Hâc İvaz bin Yûsuf ve el-Hâc Mustafa bin el-Hâc Mehmed ve Ahmed Çelebi ibn-i Mehmed ve el-Hâc Mustafa bin Ali ve el-Hâc Mustafa bin Mehmed ve İbrahim bin el-Hâc Mehmed ve es-Seyyid Ali Çelebi ibn-i es-Seyyid Mirza ve elHâc Ali bin Ahmed ve Ahmed bin Abdullah ve el-Hâc Mehmed bin Abdülkadir ve el-Hâc Hasan ve sâirleri mütemekkin oldukları odalarının içerüsine bast olunan tuğlası ve pencerelerinin ağaç 
onarım için, keşif heyetinin onarım öncesi yerinde yaptığı ölçümlere göre çıkarttığ1 onarım kalemleri, miktarları, birim fiyatları, yaklaşık maliyetleri ve onarımın toplam bedelini içeren keşif örneği aşağıda tablo 1'de sunulmuştur.

çerçeveleri ve kanadları ve ocakları ve üzerine bast olunan kurşunun bazısı fevkāni ve tahtânîde vâkı' kenîfleri ve ahûrda vâkı' kemer ayakları ve nerdübânları ve kebîr kapunın sakfı ve ba'zı mevâzı'ı mürûr-1 eyyâm ve kürûr-1 a'vâm ile harâb olmağla ve hân-1 mezbûrun odalarında mütemekkin olmakdan mezbûrûn ve misâferet vechi üzere sâkin olanlar ahurına atlarını bağlamakdan ibâ iderler taraf-1 şer'den mahalline varılup harâbe olan mevâzı'ı ne mikdar akçe ile ta'mir olunur tahmîn-i sahîh ile tahmîn olunması matlûbımdır didikde sûb-ı şer'den Mevlânâ Mustafa Efendi irsâl olunup ol dahî medîne-i mezbûrede hâssa mi'mârı kaim-i makāmı olan elHâc Mustafa ibn-i Abdullah ve zeyl-i vesîkada muharreru'l-esâmî olup emr-i bina ve sukufa vukufları olan bî-garez müslimîn ile mahall-i mezbûra varup akd-i meclis eyledikde mi'mâr-1 mezbûr hân-1 merkûmun fevkānîde vâkı' imâret ve meremmete eşedd ihtiyâc ile muhtâc olan on beş bâb odadan her bir odaya dörder yüz ellişer döşeme tuğla ve kirec ve horâsan ve ocak yaşmağı ve bacası ve pencerelerine ağaç çerçeve ve tahta kanadıyla ve üstâdiye ve irgâdiyesiyle bin yedişer yüz yigirmişer akçeden yigirmi beş bin sekiz yüz akçe ve fevkānî ve tahtânîde vâkı' kenîflerin kapuları ve sakıflarının ba'zı mevâzı'ına ve içerüsine bast olunan kayganlarını ta'mîre altı bin akçe ve fevkānîde vâkı' odaların cânib-i şimâlî ve şarkîsinin önünde olan sofalarından imâret ve meremmete eşedd-i ihtiyâc ile muhtâc olan on yedi aded odanın her birine müceddeden bast lâzım gelen tuğla ve ba'zı mevâzi'ına kaygan ve kirec ve horâsan ve üstâdiye ve irgâdiyesiyle beşer yüz akçeden sekiz bin beş yüz akçe ve hân-1 mezbûrun kapusunun elli beş zirâ' sakfının her bir ziraı tahta ve direk ve mismar ve kara çivi ve üstadiyesiyle yüz yigirmişer akçeden altı bin altı yüz akçe va hân-1 mezbûrun ahurı içinde vâkı' on beş aded kemer ayaklarının her bir ayağıyla kesme arşuna ve yigirmi sekiz ayak nerdübânın her ayağına kesme arşun taş ve kirec ve horâsan ve üstâdiyesiyle ve irgâdiyesiyle ikişer yüz ellişer akçeden yedi bin akçe ve hân1 mezbûrun ahûrı içinde vâkı' on beş aded kemer ayaklarının her bir ayağına kesme arşun taş ve battal Rumili ağacından kuşak ve dördi bir vukiyye olmak üzere her bir ayağa sekizer aded demür halka ve mismar ve kirec ve horâsan ve üstâdiye ve irgâdiyesiyle yedişer yüz ellişer akçeden on bir bin iki yüz elli akçe ve hân-1 mezbûr odalarının ve kenîflerinin bast olunan kurşun tahtasından ba'zısı ve kapu sakfının üzerine bastı lâzım gelen cem'an beş yüz aded kurşun tahtası müceddeden kal'a muhtâc olmağın beş yüz aded kurşun tahtası numûne vezn olunub beş yüz aded kurşun tahtasının her biri on yedişer vukiyyeden sekiz bin beş yüz vukıyye kurşunun her bir vukıyyesini kâle ikişer akçeden on yedi bin akçe ve her bir tahtası on sekiz vukıyye olmak üzere her tahtaya bir vukıyye cedîd kurşun zamm olunmağ çün dokuz yüz sekiz vukıyye cedîd kurşunun her bir vukıyyesine yigirmi beşer akçeden yigirmi iki bin yedi yüz akçe ve zikri sebk iden beş yüz aded kurşun tahtasını mahalline bast ve üstâdiye bin akçe ve irgâdiye ve hammaâliye ve mismârına bin beş yüz akçe ve hân-1 mezbûr dıvarlarının ba'zı mevâzı'ını kirec ve horâsan ile derze ve ba'zı mevâzı'ını tuğla ve taş ile meremmete altı bin akçe ki min haysü'lmecmû' bir yük on üç bin üç yüz elli akçe ile ancak imâret ve meremmet olunur deyû mi'mâr-1 mezbûr ve sâir vukûf ve şu' ûrı olan müslimîn icmâ' ve ittifâk eylediklerinden mevlânâ-yı mezbûr mahallinde ketb ü tahrîr idüb ba' de meclis-i şer'a gelüb vukû́' üzere inhâ ve takrîr itmeğin mâ vaka'a bi't-taleb ketb olundı fî'l-yevmi's-sâdisi aşere min Şevvâli'1-Mükerrem li-seneti semâne ve semânîne ve elf (13 Aralık 1677). B.K.S. B-140, s.91. 
Tablo 1 Pirinç Han'ında 13 Aralık 1677 tarihinde yapılan onarım öncesi keşif

\begin{tabular}{|c|c|c|c|}
\hline Yapılacak İmalatın Cinsi & Miktarı & $\begin{array}{l}\text { Birim Fiyatı } \\
\text { (Akçe) }\end{array}$ & $\begin{array}{l}\text { Maliyeti } \\
\text { (Akçe) }\end{array}$ \\
\hline $\begin{array}{l}\text { Her bir odaya, dört yüz ellişer adet döşeme tuğlası, } \\
\text { kireç, horasan, ocak yaşmağı ve bacası, pencerelerin } \\
\text { ağaç çerçevesi ve tahta kanat malzemeleriyle birlikte } \\
\text { ustalık ve amele ücretleri }\end{array}$ & 15 Adet & 1720 & 25800 \\
\hline Keniflerin kapıları, çatısı ve kaygan taşlarının tamiri & & & 6000 \\
\hline $\begin{array}{l}\text { Üst tarafta bulunan odalardan, kuzey ve doğu } \\
\text { sofalarına açılan odaların her birine lâzım gelen tuğla, } \\
\text { kireç, horasan malzemeleriyle birlikte işçilik ücretleri }\end{array}$ & 17 Adet & 5000 & 8500 \\
\hline $\begin{array}{l}\text { Han kapısının tahta, direk, ip ve kara çivi malzemesi } \\
\text { ile ustalık ücretleri }\end{array}$ & 55 Zirâ & 120 & 6600 \\
\hline $\begin{array}{l}\text { Han merdiveninin her bir ayağına büyük boy kesme } \\
\text { taş, horasan harç, ustalık ve amele ücretleri }\end{array}$ & 28 Adet & 250 & 7000 \\
\hline $\begin{array}{l}\text { Ahır içinde bulunan her bir kemer ayağına büyük boy } \\
\text { kesme taş, battal rümili ağacından kuşak, dördü bir } \\
\text { vukıyye olmak üzere sekizer adet demir halka, ip, } \\
\text { kireç, horasan, işçilik ve amele ücretleri }\end{array}$ & 15 Adet & 750 & 11250 \\
\hline $\begin{array}{l}\text { Han odalarının, keniflerin ve kapı çatısında mevcut } \\
\text { kurşunun, kurşun tahtalarında yeniden dökülmesi } \\
\text { ücreti }\end{array}$ & $\begin{array}{l}8500 \\
\text { vukiyye }\end{array}$ & 2 & 17000 \\
\hline İlave edilmesi gerekli yeni kurşun malzeme ücreti & $\begin{array}{c}908 \\
\text { vuk1yye }\end{array}$ & 25 & 22700 \\
\hline $\begin{array}{l}\text { Yeniden dökülen kurşunun mahalline serilmesi ve } \\
\text { ustalık ücretleri, }\end{array}$ & & & 1000 \\
\hline $\begin{array}{l}\text { Yeniden dökülen kurşunun işçiliği, nakliyesi ve } \\
\text { kullanılan ip malzeme ücretleri, }\end{array}$ & & & 1500 \\
\hline $\begin{array}{l}\text { Han duvarlarının bazı yerlerinde kireç ve horasan ile } \\
\text { derz yapılması, bazı yerlerinin taş ve tuğla ile onarılması } \\
\text { ücretleri }\end{array}$ & & & 6000 \\
\hline & \multicolumn{2}{|c|}{ TOPLAM } & 113350 \\
\hline
\end{tabular}

4. Onarım keşif ve raporlarının mahkeme tarafından tescil edilmesi; Naip başkanlığında hassa mimarı, bilirkişiler ve konuyla ilgisi olan diğer kişilerin de katılımıyla yerinde yapılan muayene ve tespit çalışmaları sonucu hazırlanan keşif ve raporlar, binaların bulunduğu mahallin ahalisinin de iştirakiyle kurulan mahkemede, çok sayıda şahidin takip ettiği bir oturumla şer'iye sicillerine kaydedilerek resmen tescil edilmekteydi. ${ }^{56}$ Burada, onarım belgeleri ile birlikte tüm harcama kalemleri de tek tek zapta geçirilmekteydi. 1649 yılında Yıldırım Beyazıt vakfına ait cami, türbe, medrese ve

56 Hizlı, Inşa, Tamir ve Restorasyonlar, s. 229. 
bimarhanenin bazı bölümlerinin harap olmasından dolayı talebe istinaden oluşturulan heyetin yerinde yaptığı incelemede onarım için ne tür harcamaların yapılacağı kayda geçirilmiş, toplam 32125 akçeye onarımın gerçekleşeceği konusunda "mimar-1 mezbur ve ahali-i vukuf tahmin ve ittifak eyledikleri" ne dair rapor, hassa mimarı İbrahim Efendi tarafından, mahallinde zapta geçirildikten sonra, mahkemede şer'iye sicillerine kaydedilerek tescil ettirilmiştir. ${ }^{57}$ Yine 1732 yılına ait bir belgede, Orhangazi vakfına ait cami, imaret, medrese ve türbenin onarımı için, mütevellisi Hacı Ali Ağa İbn Ahmet ve vakıf çalışanları ile mahallin ahalisinin de iştirakiyle kurulan mahkemede, mimarbaşı Seyyid Sait efendi ve diğer bilirkişilerin ittifak ile 209170 akçe olarak çıkardıkları onarım masraflarını aynı tarihte kurulan mahkemede zapta geçirerek tescil ettirdikleri belirtilmiştir. ${ }^{58}$

5. Onarım keşif ve raporlarının onay için Divan-i Hümayun'a gönderilmesi; Mahkemede tescil edilip şer'iye sicillerine işlenen onarıma ait rapor ve keşif defterleri onay için İstanbul'a "asitane-i-saadete" gönderilmektedir. ${ }^{59}$ Ancak, keşif defterleri ve diğer belgeler, mimar ve kadı tarafından imzalanıp mühürlendikten sonra öncelikle İstanbul'daki imar işlerinin nihai mercii olan hassa mimarlar ocağına, mimar ağaya gönderilmektedir. ${ }^{60}$ Burada gerekli incelemeler yapıldıktan sonra onay kararı alınması amacıyla tüm belgeler Divan-1 Hümayun'a gönderilmektedir. ${ }^{61}$

6. Onarımın onaylanması; Onarım izni için Divan'a sevk edilen rapor ve keşifler, Divan'da görüşüldükten sonra alınan onarım kararı, onay yazısı şeklinde onarımı yapılacak yapının bulunduğu yöreden sorumlu olan kadının bağlı bulunduğu mahkemeye gönderilmektedir. ${ }^{62}$ Onarım onay yazılarında, öncelikle onarım masrafının kim tarafından ve nasıl karşılanacağı açıkça belirtildikten sonra, yapılacak onarımın keşif ve raporlarda belirtilen hususlara riayet edilerek itina ile yapılması gibi uyarıcı ifadeler bulunmaktadır. ${ }^{63} 1572$ yılında Sultan Mehmed vakıfları arasında yer alan Yeşil Cami ve medresenin onarımı konusunda Divan-ı Hümayun'dan çıkan onay kararında, öncelikle onarımın tahmin edilen harcamalarının vakfın mütevellisi tarafından yapılması istenmiş olup, onarımın takip edileceği, her türlü israftan kaçınılması, onarımın tahmin edilenin de altında bir maliyetle gerçekleştirilmesi için gerekli özenin gösterilmesi emredilmiş, ayrıca onarım harcamalarının muhasebe usulüne göre deftere yazılarak, kanun ve adet olmak üzere imzalanıp, mühürlenip “Dergah-1 Muallaya” gönderilmesi gerektiği belirtilmiştir. ${ }^{64}$

7. Onarım Kararının Tebliğ Edilmesi; Divan tarafından verilen onarım onay kararı çoğunlukla yörenin kadısına ya da naibe tebliğ edilmektedir. ${ }^{65}$ Kimi durumlarda

57 Yilmaz ve Dikmen, a.g.m., s. 171

${ }^{58}$ Hizlı, İnşa, Tamir ve Restorasyonlar, s.228.

${ }^{59}$ Hizlı, İnşa, Tamir ve Restorasyonlar, s.229.

${ }^{60}$ Abdülkadir Dündar, Arşivlerdeki Plan Ve Çizimler Işı̆̆̆ Altında Osmanlı İmar Sistemi XVIII. Ve XIX. Yüzyıl, Kültür Bakanlığı Yayınları, Ankara, 2000, Osmanlı Eserler Dizisi 21, s. 90.

${ }^{61}$ Y 1 lmaz ve Dikmen, a.g.m., s. 172.

${ }^{62}$ Yilmaz ve Dikmen, a.g.m., s. 172.

${ }^{63}$ Yilmaz ve Dikmen, a.g.m., s. 172.

${ }^{64}$ Hizlı, İnşa, Tamir ve Restorasyonlar, s.232.

${ }^{65}$ Madran, Eski Eser ve Onarım, s.526. 
kararlar iki örnek hazırlanarak bir örneği yörenin bağlı bulunduğu sancak ya da eyalet yöneticisine de gönderilmektedir. ${ }^{66}$ Divandan gelen onarım onay yazısının kadı tarafından onarımın sorumlusu olan mütevelliye iletilmesiyle onarım öncesi süreç sona ermektedir.

\subsection{Onarım Süreci}

Divan'dan gelen onay kararına istinaden kadı tarafından onarımı talep edilen yapının bağlı bulunduğu vakfın mütevellisine onarım inşaatına başlama izni verilmektedir. ${ }^{67}$ Yapım aşamasında onay yazılarında belirtilen ilke ve esaslar dikkate alınarak, onarımın onay sürecinde hazırlanan keşif ve raporlara uygun olarak yürütülmesi gerekmekteydi. Vakıf yapılarında onarım inşaatı sürecinde şantiye örgütlenmesi, idari ve onarım harcamalarının gerektirdiği mali yapılanma mütevellinin yetki ve sorumluluğunda olmuştur. ${ }^{68}$ Onarım personelinin ve yapım malzemesinin temini, vakıf akarlarından gelecek gelirlerin oluşturduğu mali kaynak mütevelli tarafından çözümlenmektedir. ${ }^{69} \mathrm{Bu}$ bağlamda onarım için gerekli olan malzeme, personel ve parasal kaynağı sağlayan mütevelli onarım uygulamasına başlamaktadır. ${ }^{70}$ Mütevelli, onarım inşaatının gerektirdiği teknik ve mali alt yapıyı kurmak görevinin yanı sıra, inşaatı takip etmekle de sorumlu olmuştur. ${ }^{71}$ Vakıf yapılarında onarım inşaatında kullanılan gerekli malzemenin bazen mahalli olarak temin edildiği, fakat genellikle başka yerlerden getirildiği, malzeme fiyatlarına taşıma ücretlerinin ilave edilmesinden anlaşılmaktadır. ${ }^{72}$ Bazı vakıflarda ise, onarım için gerekli olan inşaat malzemeleri vakıfların ambarlarında el altında bulunmaktadır. Bu durum, anında tamiratın yapılarak kapsamlı onarımlara ihtiyaç duyulmamasına imkan sağlamıştır ${ }^{73}$. Onarımın yapım sürecinde mütevelliye bağlı olarak vakfın sürekli kadrosunda bulunan vakıf mimarı, onarımcılar ve onarım katibi gibi personeller de görev yapmaktaydı. Vakıf mimarının buradaki görevi onarım inşaatını yürütmek, yapılan imalatları teknik olarak kontrol etmek, onarımın daha önce hazırlanan plan, rapor ve keşiflere uygun bir biçimde gerçekleştirilmesini sağlamaktır. Kadrosunda mimar bulunmayan vakıflara ait yapıların onarımları ise, hassa mimarlarının gözetiminde yürütülmekteydi. Yapım sürecinde onarımda çalışan kurşuncu, bennâ ${ }^{74}$, neccar, su yolcu, meremmetçi gibi teknik personel, genellikle vakfın devamlı hizmetliler kadrosunda bulunan ve yapı alanında uzmanlaşmış kişilerdir.75 Ayrıca, vakıflarda her zaman için onarımla ilgili personelin istihdamı da söz konusu olmayabilir, bu durumu vakfın onarım ihtiyacı olduğu durumlarda geçici hizmet aldığı şeklinde değerlendirmek gerekmektedir. ${ }^{76}$

66 Madran, Eski Eser ve Onarm, s.526.

67 Akar, a.g.m., s. 97.

68 Akar, a.g.m., s. 97.

${ }^{69}$ Akar, a.g.m., s. 97.

70 Akar, a.g.m., s. 97.

${ }^{71}$ Madran, Eski Eser ve Onartm, s.539.

72 Bakırer, a.g.m., s.126.

${ }^{73}$ Kunter, a.g.m., s.265.

${ }^{74}$ Osmanlı döneminde yapı ustasına verilen isim.

75 Emre Madran, Osmanlı İmparatorluğu'nuın Klasik Çağlarında Onarım Alanının

Örgütlenmesi 16.-18. Yüzyıllar, ODTÜ Mimarlık Fakültesi Yayını, Ankara, 2004, s. 73.

76 Bakırer, a.g.m., s.121. 
Özellikle esaslı ve büyük onarımlarda vakıf kadrosunda bulunan personelin yetersiz kaldığı durumlarda, onarımda çalıştırılmak üzere dışarıdan geçici personel alımına da gidilmekteydi. ${ }^{77}$ Diğer yandan, vakfın kadrosunda sürekli olarak bulunmayıp onarım gerektiği durumlarda geçici onarım hizmeti veren inşaat esnafının varlığı da bilinmektedir. ${ }^{78}$ Bunlara ödenen ücretler götürü olarak ve günlük ücret tahakkuk ettirmek şeklinde ikiye ayrılmaktadır. ${ }^{79}$ Götürü yöntemde, yaptırılan belirli bir iş karşılığ1 iş öncesi yapılan anlaşmaya göre ücret ödenmektedir. Günlük ödeme yönteminde ise, çalışılan gün başına önceden belirlenen ücret ödenmektedir. Onarım çalışmasının yapım sürecinde görev alan onarım katipleri ise, çoğunlukla vakfın sürekli kadrosunda bulunmaktadır. Onarım katibinin görevi, onarım esnasında sarf olunan malzemelerin miktarını, bunlara ödenen paraları, çalışma günlerini, çalışan işçi, usta, kalfalara ödenen ücretleri, nakliye masraflarını ve sarf giderleri günlük olarak onarım inşaat defterine kayıt etmekti. ${ }^{80}$ Ayrıca, onarım inşaatının gerektirdiği her türlü giderlerin ödemeleri de mütevelli adına onarım katipleri tarafından yapılmaktaydı. 1627 tarihli Yeni Cami vakfiyesinde, gündeliği on akçe olan bir kişinin onarım katibi olacağı ve tamirata sarf olunan tüm parayı deftere yazıp, bunların ödemelerini de dikkatli bir biçimde yapması gerektiği belirtilmiştir. ${ }^{81}$ Onarım inşaat defterlerine yapım sürecinde onarım katibi tarafından kayıt edilen tüm harcama kalemleri, inşaat tamamlandığında tek tek toplanarak onarımın gerçek maliyeti elde edilmekteydi. Orhangazi vakfına ait Bursa'da bulunan Orhangazi Camisi'nin 1773 yılında yapılan onarımında, onarım katibi tarafından tutulan inşaat defterine göre, cami üzerinde bulunan kurşunun kalyesi ${ }^{82}, 6$ adet sofanın beyaz sıvaları, kubbelerin etrafındaki derzler, kubbelerin temizlenmesi ve anbar aktarması, 6 adet pencerenin çerçeveleri ve camlarının yenilenmesi, harim duvarlarının horasan sıva ile tamiri ve diğer işler için kurşun, hatıl, toprak, kireç, tuğla kırığ1, urgan, kürek, cam, tahta gibi malzemelerin alınması ve bunların nakliyeleri, ayrıca işçilik ödemeleri toplanarak onarıma 82340 akçe harcandı̆̆

Diğer yandan, masrafları devlet hazinesinden ödenecek olan sultan vakıflarının büyük çaplı onarımlarında, malzeme ve onarım personelinin temini, nakliyeler ve bunlara ödenen ücretler önceden atanan bina eminleri vasitasiyla gerçekleştirilmekteydi. Bina eminleri, devlet tarafından onarım için kendilerine verilen paraları yerli yerinde harcamakla yükümlüdürler. ${ }^{84} \mathrm{Bu}$ yapıların onarım inşaatını

77 Madran, Eski Eser ve Onarm, s.540.

78 Madran, Onarım Alanın Örgütlenmesi, s. 89.

79 Madran Emre, Osmanlı İmparatorluğunda Onarım Esnafı 16.-18. Yüzyıllar, Editörler, Nur Akın, Afife Batur ve Selçuk Batur, Osmanlı Mimarlığının 7 Yüzyılı Uluslarüstü Bir Miras, Yem Yayınları, İstanbul, 1999, s. 332.

80 Dündar, a.g.e., s. 95.

81 Ali Sami Ülgen, "Yeni Cami", Vakıflar Dergisi, Vakıflar Genel Müdürlügü̈ Yayınları, S. II, Ankara, 1942, s. 396.

82 Bina üzerinde bulunan mevcut kurşunun sökülüp eritildikten sonra, tahta kalıplara dökülerek soğutulmasıyla elde edilen yeni kurşun levhaların tekrar kullanılması işlemine verilen isimdir.

83 Bakırer, a.g.m., s.124.

${ }^{84}$ Dündar, a.g.e., s. 84 . 
yürütmek ve onarımın teknik kontrolünü yapmak amacıyla da hassa mimarları görevlendirilmiştir. ${ }^{85}$

\subsection{Onarım Sonrası Süreç}

Onarım sonrası süreç, onarım tamamlandıktan sonra yapılması gereken kontrol ve kesin kabul işlemlerini içermektedir. İnşaatın bitiminde, onarımın daha önce hazırlanan rapor ve keşif defterlerinde sözü edilen hususlara uygun olarak yapılıp yapılmadığının belirlenmesi için yerinde incelenerek son bir keşfin, yani bir nevi kesin kabulün yapılması gerekmekteydi. ${ }^{86} \mathrm{Bu}$ nedenle, onarım sonrası sürecini aynı zamanda onarımın aklanma süreci olarak nitelendirmek de mümkündür. Onarımın aklanması amacıyla, vakfın nazırı ya da mütevellisi tarafından mahkemeye müracaat edilerek onarımın tamamlandığı belirtilmekte, onarıma harcanabilecek paranın tespit edilmesi amaciyla onarımın yerinde incelenmesi mahkemeden talep edilmektedir. Bu talebe karşılık kadı tarafından kurulan heyette hassa mimarı, ehl-i vukuf kimseler ve bî-garez müslümanlar bulunmaktaydı. Onarılan yapıyı yerinde inceleyen heyet, öncelikle onarımın gerçekleşip gerçekleşmediğini ve yapımın onarım öncesi hazırlanan keşif ve raporlara uygun olarak yapılıp yapılmadığını kontrol eder, daha sonra da onarım için ne kadar para harcanmış olabileceğini hesap ederdi. Onarım için yapılan masrafların tespit edilmesi konusu arşiv belgelerinde tahammüli keşif miktarının belirlenmesi olarak ifade edilmektedir (Belge 4). ${ }^{87}$ Bu nedenle, onarım sonrası mütevelli tarafından mahkemeden istenen maliyet tespiti talebini, onarımın tahammüli keşfinin belirlenmesi talebi olarak isimlendirmek de mümkündür. Bu bağlamda, onarımın kaça mal olacağ1 heyetin yerinde yaptığı ölçümlemelerle belirlenmekteydi. Heyet tarafından yapılan bu son kontrol ve tahammüli keşif ile birlikte binaların kullanıma hazır hale gelip gelmediği, onarımın usulüne uygun olarak yapılıp yapılmadığı mahkemeye rapor edilmekteydi. Raporun kadı tarafından mahkemede kayıt altına alınmasıyla kesin kabul yapılarak onarım aklanır ve bu durum vakfın mütevellisine bildirilirdi.

1574 yılının mart ayında Bayezid Vakfı'nın müderrisi İvaz Efendi ibn-i Abdülkerim Efendi, vakfa ait Pirinç Hanın doğu duvarının yanından geçen kâriz su yolu ile üzerindeki harap olmuş döşemeyi tamir ettirdiğini, heyet kurularak kontrol edilmesini ve onarımın kaça mal olacağının belirlenmesi için keşif yapılmasını mahkemeden talep etmiştir (Belge 5). ${ }^{88}$ Bunun üzerine kadı Mehmed Vahidi Efendi tarafından hassa

85 Turan, a.g.m., s. 170. Bkz. Bakırer, a.g.m., s. 122.

86 Madran, Eski Eser ve Onarım, s.532.

87 mezkūreyi māl-i vakf-1 muşarunileyh ile bi'l-izni'ş-şer'ī tecdīd ve meremmet eyledim taraf-1 şer'den üzerlerine varılub masrūfım olan meblağın mertebe-i tahammüli keşf $u$ tahmīn ve tahrīr olunması matlūbımdır. B.K.S. .B-116, s.19.

${ }^{88}$ Merhūm ve mağfūrun leh cennetmekân huld-âşiyân Sultan Bayezid Hân-1 Velî tâbe serah evkāfı müstagıllâtından olup mahrūse-i Brusa'da vakı' Pirinç Hanı dimekle ma'rûf hāna hâlen kâimmakām-1 nâzır olan umdetu'l-muderrisîni'l-kirâm İvaz Efendi ibn-i Abdülkerim Efendi meclis-i şer'-i şerîfde takrîr-i kelâm ve ta'bîr-i ani'l-merâm idüp zikrolunan hanın taraf-1 garbîsinde vâkı' dıvarın yanından cereyan iden kârîz suyunun üzerinin mürûr-1 eyyâm ile döşemesi bi'l-külliye harâb ve ekser mevâzı'ı münhedim olup ta'mîre eşedd-i ihtiyâcla muhtâc olmağın bundan akdem kıbel-i şer'den mâl-i vakf-ı mezbûr ile ta'mîr ve termîme izin ve icâzet virildiğin ben dahî zikrolunan kârizi ta'mîr ve termîm itmekle hâlen üzerine varılup masrûfım olan meblağın tahammüli keşf ü tahrîr olunması matlûbımdır didikde sûb-ı şer'den Mevlânâ 
mimari el-Hâc Mustafa ile birlikte ehl-i vukûf müslümanlardan oluşan bir heyet kurulmuştur. Heyetin yerinde yaptığı incelemede, kariz yolu tamirinin 92 zirâ uzunlukta, 2 zirâ genişlikte bulunduğu, satrancini hesabıyla 194 zirâ tuttuğu, onarımın toplam 11112 akçeye tahammüli olduğu belirlenmiştir. ${ }^{89}$

Diğer bir arşiv belgesine göre, Sultan Murad Vakfı'nın bir önceki mütevellisi olan Kâsım Bey, vakfa ait imarethanede kadın misafirlerin konaklaması için kullanılan tabhaneyi odun anbarına dönüştürmüş idi. Vakfa atanan yeni mütevelli Mustafa Bey ise, burasını yıkarak kadın misafirlerin konaklaması için yeniden tabhaneye dönüştürmüştür. İnşaatı tamamlayan mütevelli mahkemeye yaptı̆̆ı müracaatta heyet kurularak onarımın kaça mal olacağının belirlenmesini talep etmiştir (Belge 6). ${ }^{90}$ Bunun üzerine kadı Ahmed bin Mehmed tarafından içinde hassa mimarı İbrahim bin Bayram, ehl-i vûkuf ve bî-garez müslümanların bulunduğu bir heyet kurulmuştur. Onarımı yerinde kontrol eden heyetin satrancini yöntemiyle yaptığı alan hesabında, imalatın eni ve boyu çarpılarak 180 zîra olduğu belirlenmiştir. Heyet tarafından, tabhanenin onarım ve yenilenmesi için kullanılan çatının kiremidi ve döşenmesi, tuğla, çivi, mertek ve sair kereste malzeme miktarları, bunların işçilik ve nakliye ücretleri hesaplanarak onarımın 25000 akçeye mal olabileceği saptanmış, tutulan rapor kadı tarafından 16 Aralık 1603

Mehmed Vahîdî Efendi ve hâssa mi'mâr kāyim-i makāmı el-Hâc Mustafa irsâl olunup ol dahî zeyl-i vesîkada muharreru'l-esâmî olan ehl-i vukûf müslimîn ile mahall-i merkûma varup ba'de'n-nazar kāim-i makām-1 mi'mâr-1 mersûm el-Hâc Mustafa mesâha eyledikde zikri mürûr iden kârîzin bennâ zirâı'yla tûlan doksan iki zirâ' ve arzan iki zirâ'ki be-hesâb-1 satrancî yüz seksen dört zirâ' kârîz ile bir kapu binâsının ta'mîr ve termîmine merkûm İvaz Çelebi'nin on bir bin yüz on iki akçe sarf olunmuş bulunup zikri sebk iden kârîz ta' mîrine meblağ-1 mezkûr on bir bin yüz on iki akçeye tahammülü olduğunu mi'mâr-1 mezbûr ve sâyir ehl-i vukûf müslimîn ihbâr eylediklerinde vâkı' hâli Mevlânâ-yı mezbûr mahallinde tahrîr ba'de ba's olunan Ebûbekir bin Mustafa nâm kimesne ile meclis-i şer'a gelüp alâ vukû'ihi inhâ ve tefhîm itmekle mâ vaka'a bi'ttaleb ketb olundu fi'l- yevmi'l-hâmisi min zilhicceti'ş-şerîfe li-seneti ihdâ ve semânîne ve elf (28 Mart 1574 Pazar). B.K.S. B-90, s. 79.

${ }^{89}$ Bir zirâ günümüzde $0.57417 \mathrm{~m}^{2}$ dir, 194 zirâ ise, $194 \times 0.57417=111.39 \mathrm{~m}^{2}$ yapmaktadır.

${ }^{90}$ Mahrûse-i Brusa' da vâkı' merhûm ve mağfûrun leh Sultan Murad Hân-1 Sânî evkāfının bi'l-fiil mütevellîsi olan fahru'l-akrân Mustafa Beg ibn-i İskender mahfil-i kazâda takrîr-i merâm idüb bundan akdem evkāf-ı mezbûra mütevellî olan Kāsım Beg evkāf-1 mezbûr imâret-i âmiresinin havâtun içün kadîmden vaz' olan tabhânesini yıkub imâret-i mezbûrenin odun anbarı itmekle imâret-i merkûmeye misafir olub âyende ve revende havâtun tâyifesine tabhâne-i uhrâ binâ olunmağa sûb-1 şer'den izin ittirdikten sonra alâ vechi'l-istihkâm binâ olunmasîçün emr-i celîlü'lkadrden varid olmuşidi el-hâletü hâzihî mûceb-i emr-i şerîf evkāf-1 mezbûrenin imâret-i âmiresi mezbûre havâtun tâyifesîçün mücedded iki bâb tabhâne itdim cânib-i şer'i şerîfden üzerine âdem gönderilüb ne mikdâr akçe harc ü sarf olunduğına tahammüli olduğın görülmesin taleb iderim didikde cânib-i şer'den Mevlânâ Ahmed bin Mehmed irsâl olunub ol dahî hâssa mi'marlardan el-Hâc İ̉rahim bin Bayram ve ehl-i vukuf ve bî̀-garez Müslümanlar ile üzerine vardıkda fi'l-vâkı' vâkıf-1 mumaileyh imâret-i âmirenin cânib-i şarkîsinde vâkı' bi hesâb-1 şatrancî binâ zirâ'ıyle tûlan ve arzan yüz seksen zirâ' iki bâb tabhâne müceddeden bina olunmuş bulunub zikrolunan iki bâb tabhânenin sakfının kiremidine ve döşenmesine, tuğlasına ve mismârına ve merdeklerine vesâyir kerâste-i malzemesine ve bennâ ve irgâdiyesine cem'an yigirmi beş bin akçeye tahammüli oldığın mevlânâ-yı merkûm ile mi'mâr-1 mezbûr gelüb meclis-i şer'de haber virmegin mâ cerâ alâ vukû'in Mustafa Beg'in talebiyle ketb ü tahrîr olundı hurrire fi'l-yevmi's-sânî aşere min recebi'l-müreccebli-seneti isnâ aşrete ve elf 12 Receb 1012 (M. 16 Aralık 1603). B.K.S. A.155, s. 75/1. 
tarihinde zabta geçirilmiştir. Yine bir arşiv belgesine göre, 1603 tarihinde Sultan Murad Vakfı'nın mütevellisi Mustafa Bey, vakfa ait medresenin harap olan on altı adet odasının kapısını, pencerelerini, sofanın ve haremin döşemesini, sıvalarını tamir ettirdiğini belirterek onarımın kaça mal olabileceğinin belirlenmesi amacıyla mahkemeden tahammüli keşif yapılmasını talep etmiştir (Belge 7). ${ }^{91} \mathrm{Bu}$ talep üzerine kadı Mevlânâ Ahmed tarafından, hâssa mimarlarından el-Hâc İbrahim ile ehl-i vukûf ve bî-garez müslümanlardan oluşan bir heyet kurulmuştur. Kurulan heyetin yerinde yaptığı incelemede; malzeme, işçilik ve nakliye masrafları ayrı ayrı çıkartılarak onarımın 16000 akçeye mal olacağı hesaplanmış, tutulan rapor ve keşif miktarı mahkeme tarafından tescil edilmek üzere zabta geçirilerek onarım aklanmıştır.

Bursa Kadı Sicillerinden elde edilen diğer bir arşiv belgesine göre de, 19 Kasım 1671 tarihinde Sultan Bayezid vakıflarından Pirinç Han'ın nazırı İvaz Efendi mahkemeye gelerek, şadırvan ile su yollarını, taksim yerlerini, cami ve tuvaletlerin üzerindeki kurşunların yenilenme ihtiyacı bulunan harabe-i müşrif olmuş kısımlarını vakfın kaynaklarıyla onardığını belirtmiştir. Vakfın nazırı, yapılan bu onarımın yerinde incelenmesini ve tahammüli keşfinin çıkartılmasını mahkemeden talep etmiştir. Bunun üzerine mahkeme başkanı kadı Mustafa Efendi tarafından içinde hassa mimarlarından Mehmed bin Abdullah ile birlikte ehl-i vukuf ve bì-garez müslümanlardan oluşan bir heyet kurulmuştur. Heyetin yerinde yaptığ 1 incelemede, öncelikli olarak onarımın daha önce belirlenen keşif ve raporlara uygun olarak gerçekleşip gerçekleşmediği kontrol edildikten sonra, onarım için yapılan masrafların tespitine geçilmiştir. Onarımda kullanılan malzemeler, işçilikler ve nakliyeler tespit edilerek kalem kalem çıkartılmış, bu kalemler günün cari fiyatlarıyla çarpılarak onarımın tahammüli keşfi hazırlanmıştır. Heyet tarafından yapılan maliyet hesabında, onarımın toplam 23621 akçeye mal olabileceği tespit edilmiştir (Belge 4). ${ }^{92}$ Hassa mimarı ve heyette bulunan diğer kişilerin

\footnotetext{
${ }^{11}$ Mahrûse-i Brusa' da vâkı' Merhûm Sultan Murâd Hân-ı Sânî evkâfının mütevellîsi olan fahru'1emâcid Mustafa Beg ibn-i İskender mahfil-i kazâda takrîr-i merâm idüb vâkıf-ı mumaileyhin mahrûse-i merkûmede vâkı' medresesinin mürûr-1 eyyâm ile on altı bâb hücerâtının kapuları ve pencereleri ve musandıraları ve sofalarının ve hareminin döşemeleri ayağları ve sıvaları harâbemüşrif olub ta'mîr ve meremmetîçün yedimde emr-i celîlü'l-kadr almışidim hâlen medrese-i merkûmenin ta'mîr ve meremmete muhtâc olan mevâzi'i görülmesin taleb iderim didikde cânibi şerîat-1 mutahharadan Mevlânâ Ahmed irsâl olunub ol dahî hâssa mi'marlardan el-Hâc İbrahim bin el-Hâc Bayram ve zeyl-i kitâbda isimleri mestûr olan ehl-i vukuf ve bî-garez Müslümanlar üzerine vardıkda fi'l-vâkı' medrese-i merkûmenin on altı bâb hücerâtının kapuları ve pencereleri ve musandıraları ve sofalarının ve hareminin döşemeleri ve ayağları ve sıvaları ta'mîr ve meremmet olunmuş bulunub zikr olunan mevâzi'in ta'mîr ve meremmetîçün harc ü sarf olunan kerâste ve lâzimesinin ve bennâ ve irgâdiyesinin cem'an on altı bin akçeye tahammüli olduğın mevlânâ(-yı) muşarunileyh ile mi'mâr-1 mezbûr gelüb meclis-i şer'de haber virmegin mâ hüve'1vâkı' bi't-taleb ketb ü tahrîr olundı fi't-târîhi'l-mezbûr. B.K.S. A.155, s. 75/2.

92 Dāru's-Saltanati'l Aliyyeti'l-Kostantiniyyeti'l-Mahmiyye'de merhūm ve mağfūrun leh Sultan Bayezid-i Velī aleyhi rahmeti'l-Melikü'l- Bārī evkafı müstagıllātından Mahrūse-i Brusa'da vakı' Pirinç Hanı dimekle meşhūr hān-ı cedīd-i sānī ve hān-1 cedīd-i evvelin men lehü'l-emr kıbel-i ālīlerinden nāzırı olan işbu bā'isu'l-kitāb İvaz Efendi ibn-i Abdülkerim Efendi meclis-i şer'de takrīr-i kelām ve bast-1 merām idüb sālifu'l-beyān hān-1 cedīd-i sānīnin fevkānī kenīflerine Serpınar nām nehirden cārī mānın ekser mecrāsı ve mā-i mezbūrun maksem ve terāzūsı ile içeru ve taşra şadırvanlarının bazı mevāzı'ı ve hān-ı cedīd-i evvelin mescid-i şerīf ve tahtānī kenîfleri
} 
ittifak halinde çıkarttıkları tahammüli keşif miktarı ile onarıma ait raporlar mahkemede kayıt altına alınarak onarım aklanmıştır. Keşif heyeti tarafından çıkartılan onarımda yapılan işlere ilişkin, onarım miktarları ve maliyetlerini içeren tahammüli keşif hesabı Tablo 2' de sunulmuştur.

Tablo 2. 1671 tarihinde Pirinç Han'ın onarımı sonrası çıkartılan tahammüli keşfi

\begin{tabular}{|l|c|c|}
\hline Yapılan İşin Adı & Miktarı & Maliyeti \\
\hline $\begin{array}{l}\text { Taksim yerine kadar büyük künklerin yenilenmesi, } \\
\text { (künk ile harpuşta için kireç, horasan, lökün ve işçilik) }\end{array}$ & 398 adet & 7960 Akçe \\
\hline Tuvaletlere giden künklerin yenilenmesi, tanesi11 akçeden, & 488 adet & 5368 Akçe \\
\hline Taksim yerinin onarımı için kireç ve lökün masrafı, & & 1550 Akçe \\
\hline Mevcut kaldırımın tamiratı, & & 700 Akçe \\
\hline Kaldırım, kireç ve horasanı ile nakliyesi, & & 372 Akçe \\
\hline Kaldırım, kireç ve horasan işçi ücretleri, & & 425 Akçe \\
\hline Kaldırım için usta ücretleri, & & 400 Akçe \\
\hline Tuvaletlerin temizlenmesi, & & 200 Akçe \\
\hline Tuvaletlerin tahta, hatıl ve direklerine, & & 520 Akçe \\
\hline Çivi ücreti, & & 200 Akçe \\
\hline Dış şadırvanın tırabzanı, sair malzemelerle birlikte, & & 800 Akçe \\
\hline İç şadırvan tamiri, lökünü ve işçilik ücreti, & & 580 Akçe \\
\hline Bezir yağı, & & 200 Akçe \\
\hline Caminin kubbe derelerinin kurşunu, vukıyyesi 26 akçeden, & 47 vukıyye & 1222 Akçe \\
\hline Çivi ve mevcut kurşunların yeniden kaplanması & & 406 Akçe \\
\hline Tuvaletlerde yenilenen tahtaların üzerine kurşun örtülmesi, & 68 vukıyye & 1768 Akçe \\
\hline 400 vukıyye mevcut kurşunun yeniden kaplanması, & & 800 Akçe \\
\hline Tahta kaplama ücreti, & & 40 Akçe \\
\hline Çivi ücreti & & 30 Akçe \\
\hline 2 kez yapılan kurşun nakliye ücreti & 80 Akçe \\
\hline & Toplam & 23621 Akçe \\
\hline
\end{tabular}

üzerlerinin kurşunları mürūr-1 eyyām ve kürūr-1 a'vām hasebi ile müşrif-i harāb ve māyil-i turāb olub tecdīd ve meremmet olunmağa eşedd-i ihtiyaç ile muhtāc idüğin bundan akdem zikirleri sebk iden hanlar ahālīsi ba'de'l-ihbār hālen mevāzı-1 mezkūreyi māl-i vakf-1 muşarunileyh ile bi'l-izni'ş-şer'î tecdīd ve meremmet eyledim taraf-1 şer'den üzerlerine varılub masrūfım olan meblağın mertebe-i tahammüli keşf $\mathrm{u}$ tahmīn ve tahrīr olunması matlūbımdır didikde sūb-1 şer'den Mevlānā Mustafa Efendi ibn-i İbrahim Efendi bi't-taleb irsāl olunub ol dāhī mahrūse-i mezbūrede hāssa mi'mar kaimmakamı olan Üstad Mehmed bin Abdullah ve zeyl-i sütūrda mestūru'l-esāmī olub ebniye ve sukūf ahvāline vukūf ve şuūrı olan bī-garez müslimīn ile sālifu'zzikr hanlara varılub ba'de'n-nazar fi'l-vākı' merkūm İvaz Efendi mevāzı-1 mezkūreyi tecdīd ve meremmet eylediği zāhir ve müteayyin oldukdan sonra mi' mār-1 mezbūr Mehmed mersūm İvaz Efendi'nin tecdīd ve meremmet itdüği mevāzı-1 mezkūreyi misbāh mesāh ve kıymet-i takvīm eyledikde mahrūse-i mezbūreye, cem'an yigirmi üç bin altı yüz yigirmi bir akçe ve sarf olunmuş bulunub ebniye-i mezkūre meblağ-1 masrūf-1 mezbūr ile ancak vücuda gelür noksan ile mümkün değildir deyū mimār-1 mezbūr ve sāyir ahālī-i vukuf ve şuūr icmā ve ittifak eylediklerin mevlānāyı merkūm mahallinde ketb ü tahrīr ba' de meclis-i şer'a gelüb alā vukū'ihi inhā ve takrīr itmegin mā vaka'a bi't-taleb ketb olundu fi'l-yevmi's-sādisi aşere min Recebi'l-murecceb li seneti isneyni ve semānīne ve elf (Miladi 19 Kasım 1671 Perşembe) B.K.S. B-116, s. 19. 


\section{Sonuç}

Klasik Osmanlı döneminde, vakıf yapıların onarım harcamaları her ne kadar vakfın mütevellisi tarafından karşılanmakta ise de, yapılacak onarımın gerekliliği, kapsamı ve maliyeti için, içinde yerel ahalinin de bulunduğu tüm paydaşları içeren katılımcı onarım süreçleri kullanılmıştır. Onarım öncesi ve onarım sonrası süreçler, resmi işlemlerin yürütüldüğü ve birbirine benzer aşamalar içeren süreçlerdir. Her iki süreçte de mahkeme tarafından kurulan ve içinde hassa mimarlarının da bulunduğu heyet; onarım öncesinde onarıma ait yaklaşık maliyeti içeren keşif ve raporları hazırlamakta, onarım sonrasında ise, onarıma harcanan paranın belirlenmesi amacıyla tahammüli keşif çalışması yapmaktaydı. Görüldüğü gibi, klasik çağlarda katılımcı çalışmaların ürünü olan maliyet tespiti yapılmadan, vakıf yapılarında bir onarım çalışmasının başlamasına ya da onarımın aklanarak sonuçlanmasına izin verilmemekteydi. Bunun nedeni, onarımla ilgili yapı faaliyetlerinde ortaya çıabilecek olası suiistimallerin önüne geçilmesi olduğu gibi, özellikle maliyete ilişkin işlemlerde planlanma ve kontrol olanağ sağlanarak onarımın garanti altına alınmasıdır.

İncelenen dönemde, onarım süreçlerini yöneten ve süreçlerde yürütülen işlemlerde etkili olan kurum ve kişilerin nitelikleri de değişmektedir. Buna göre, onarımın yapım öncesi süreci ile yapım sonrası kesin kabul sürecinin her aşamasında etkili mevki olarak kadılar görülmekle beraber, uygulama aşamasındaki yapım sürecini yürüten vakıf mütevellisinin yapım ve organizasyon çalışmalarını tümüyle yönettiği görülmektedir.

Diğer yandan, gerek klasik dönem sonrası geç Osmanlı'da, gerekse günümüz Türkiye' sinde vakıf yapıların onarımlarında onarım kararını veren, onarım çalışmalarını yürüten kurumların isimleri, nitelikleri ve koruma anlayışları yüzyıllar içinde değişse de, klasik dönemde kullanılan onarım aşamalarının sonraki dönemlerde de benzer şekillerde kullanıldığı görülmüştür. Ancak vakıf yapılarında onarımın önemi, gerekliliği ve önceliği anlayışının diğer dönemlere göre Klasik Osmanlı döneminde daha etkili olduğu anlaşılmaktadır. Bu nedenle, Osmanlıların klasik çağlarda sosyal hizmetlere adanmış olan vakıf yapılarını korumada, dolayısıyla bunların onarım süreçlerinde gösterdikleri titiz davranışlar, bu yapıların sürekli kullanımına imkan veren önemli bir temel oluşturmuştur.

Tüm bunların 1şığında, Klasik Osmanlı döneminde vakıf yapıların onarım etkinliklerinde yürütülen süreçlerin, klasik dönem sonrası merkezi idare altında devlet birimlerince yürütülen her aşamadan, daha şeffaf ve katılımcı olduğu saptanmıştır. Bu bağlamda vakıf yapıların, 16. yüzyıldan başlayarak 19. yüzyılın ilk yarısına kadar devam eden klasik dönemde, onarımların vakıf sistemi içindeki koruma-onarım döngüsünden uzaklaştığı sonraki dönemlere göre daha iyi korunduğu anlaşılmaktadır. 


\section{KAYNAKÇA}

\section{Arşiv Belgeleri}

Belge 1. Bursa Kadı Sicilleri, B-129, s. 139. Yayınlanmamış Arşiv Belgesi.

Belge 2. Bursa Kadı Sicilleri, A-94， s. 36. Yayınlanmamış Arşiv Belgesi.

Belge 3. Bursa Kadı Sicilleri, B-140, s. 91. Yayınlanmamış Arşiv Belgesi.

Belge 4. Bursa Kadı Sicilleri, B-116, s. 19. Yayınlanmamış Arşiv Belgesi.

Belge 5. Bursa Kadı Sicilleri, B-90, s. 79. Yayınlanmamış Arşiv Belgesi.

Belge 6. Bursa Kadı Sicilleri, A-155, s. 75/1. Yayınlanmamış Arşiv Belgesi.

Belge 7. Bursa Kadı Sicilleri, A-155, s. 75/2. Yayınlanmamış Arşiv Belgesi.

\section{Yayınlanmış Eserler}

AMY, Singer, Osmanlı'da Hayırseverlik Kudüs'te Bir Haseki Sultan Imareti, Çev. Dilek Şendil, Tarih Vakfı Yurt Yayınları, İstanbul, 2004.

AKAR, Tuba, “Tanzimat Öncesinde Vakıf Kurumu Ve Yapıların Korunması” Vakıflar Dergisi, Vakıflar Genel Müdürlüğü Yayınları, S. 33, Ankara, 2010, s. 89-110.

BAKIRER, Ömür, "Vakfiyelerde Binaların Tamiratı ile İlgili Şartlar ve Bunlara Uyulması", Vakıflar Dergisi, S. X, Ankara, 1973, s. 113-126.

DUYMAZ, A. Şevki, “II. Abdülhamit Dönemi İmar Faaliyetleri”, Süleyman Demirel Üniversitesi Sosyal Bilimler Enstitüsü, Yayınlanmamış Doktora Tezi, Isparta, 2003

DÜNDAR, Abdülkadir, Arşivlerdeki Plan Ve Çizimler Işı̆̆̆ Altında Osmanlı İmar Sistemi (XVIII. Ve XIX. Yüzyıl) , Kültür Bakanlığı Yayınları, Osmanlı Eserleri Dizisi, Ankara, 2000.

EFENDİ, Ömer Hilmi, İthaf-ül-Ahlâf fi Ahkâm-il-Evkaf, Vakıflar Genel Müdürlüğü Yayınları, Ankara, 1977.

ERDOĞAN, Muzaffer, “Osmanlı Devrinde Anadolu Camilerinde Restorasyon Faaliyetleri" Vakıflar Dergisi, S. VII, Ankara, 1968, s. 149-205.

ERTEM, ADNAN, “Osmanlıdan Günümüze Vakıflar” Vakıflar Dergisi, S. 36, Ankara, 2011, s. 25-65.

GÜLTEKİN, A.Tanju, "Proje Yönetimi, Yapım Öncesi Süreç", Palme Yayıncılık, Yayın no. 447, Ankara, 2007.

HIZLI, Mefail, "Osmanlı Vakıf Eserlerinin İnşa, Tamir ve Restorasyonları" Uludă̆ Üniversitesi Illahiyat Fakültesi Dergisi, C. 5, S. 5, Bursa, 1993, s. 219-232. 
HIZLI, Mefail, “Osmanlı Vakıf Sisteminde Rakabe” Uludağ Üniversitesi İlahiyat Fakültesi Dergisi, C. 6, S. 6, Bursa, 1994, s. 53-70.

KONYALI, İsmail Hakkı, “Kanuni Sultan Süleyman'ın Annesi Hafse Sultan'ın Vakfiyesi

ve Manisa' daki Hayır Eserleri" Vakıflar Dergisi, S. VIII, Ankara, 1969, s. 47-56.

KUNTER, Halim Baki, “Türk Abidelerinin İdare, Muhafaza, Bakım ve Onarım Mevzuunda Tatbik Edilmiş Olan Esaslar", Uluslararası I. Türk Sanatları Kongresi Tebliğleri, Ankara, 1959, s. 260-267.

MADRAN, Emre, “Osmanlı Devletinde Eski Eser Ve Onarım Üzerine Gözlemler” Belleten, Türk Tarih Kurumu Yayını, C. XLIX, S. 195, Ankara, 1985, s. 503-546.

MADRAN, Emre, Osmanl İmparatorluğunda Onarım Esnafı 16.-18. Yüzyıllar, Editörler, Nur Akın, Afife Batur ve Selçuk Batur, Osmanlı Mimarlığının 7 Yüzyılı Uluslarüstü Bir Miras, Yem Yayınları, İstanbul, 1999, s. 327-335.

MADRAN, Emre, Osmanlı Imparatorluğu'nun Klasik Çă̆larında Onarım Alanının Örgütlenmesi 16.-18. Yüzyıllar, ODTÜ Mimarlık Fakültesi Yayını, Ankara, 2004.

ÖCALAN, Hasan Basri, Sevim Sezai, Yavaş Doğan, Bursa Vakfiyeleri 1, Bursa Büyükşehir Belediyesi Kültür A.Ş Yayınları, C.1, Bursa, 2013.

TURAN, Şerafettin, “Osmanlı Teşkilâtında Hassa Mimarları” Tarih Araştırmaları Dergisi 1, Ankara, 1963, s. 159-200.

ÜLGEN, Ali Sami, “"YYeni Cami” Vakıflar Dergisi, Vakıflar Genel Müdürlüğü Yayınları, S. II, s Ankara, 1942, 387-398.

YAVAŞ, Doğan, Bursa'nın Kalbi Ulucami, Editörler, Mustafa Kara ve Bilal Kemikli, Bursa İl Özel İdaresi Yayını, Bursa, 2009, s. 133-142.

YAVAŞ, Doğan, "Bursa Yeşil Cami'de yapılan Onarımlar" XIV. Ortaçă̆ ve Türk Dönemi Kazıları Ve Sanat Tarihi Araştırmaları Sempozyumu Tebliğleri, Konya 2011, s. 629-640.

YILMAZ, İbrahim, Dikmen S. Ümit, “Osmanlı Döneminde Yapıların Onarım ve Restorasyonunda Tasarım Ve Onay Süreci”, 23.Uluslararası Katılımlı Yapı ve Yaşam Kongresi, Tebliğleri, Mimarlar Odası Bursa Şubesi, Bursa, 2011, s.169-173. 


\section{ARŞIV BELGELERI}

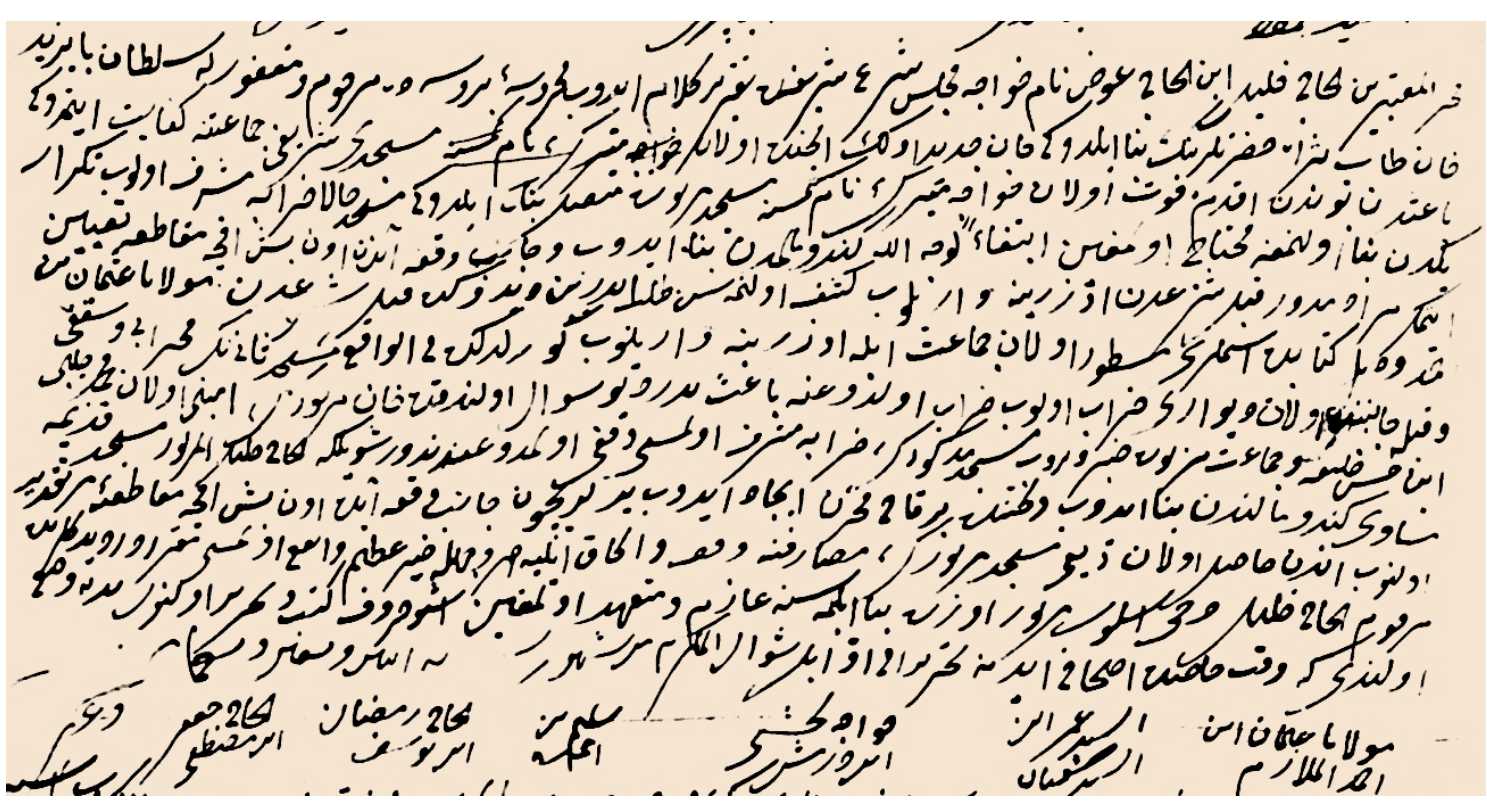

Belge 1. Ekim 1584 yılında Pirinç Han'ın içinde bulunan mescidin onarımı için yöre halkından el- Hac Halil'in mahkemeye yaptı̆̆ı talebi gösteren arşiv belgesi. B.K.S. B-129, s. 139.

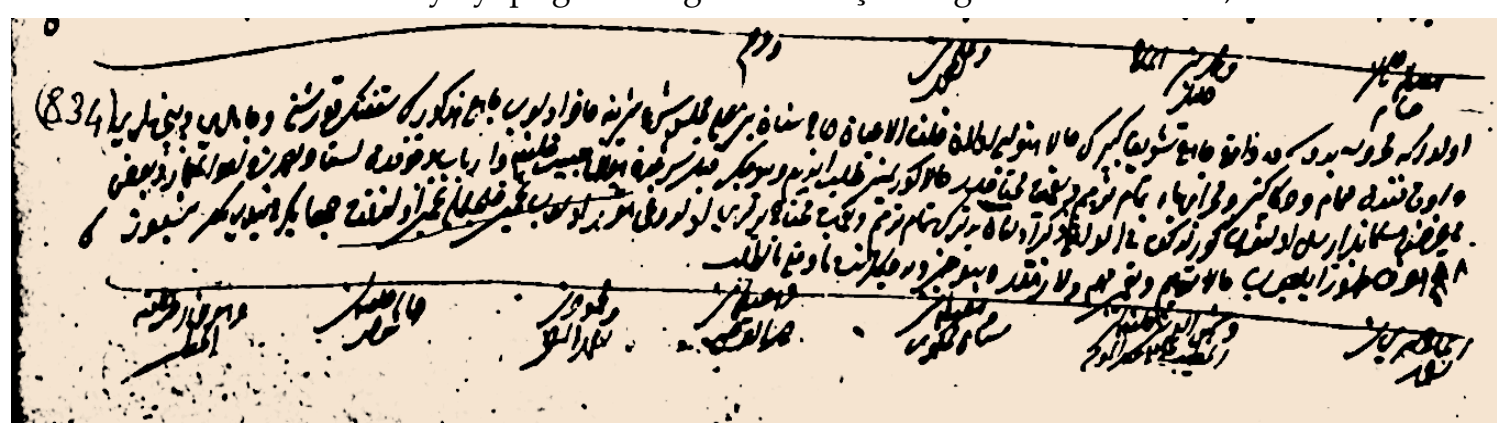

Belge 2. 15 Aralık 1567 tarihinde, Bursa Ulucami mütevellisi Sinan bin Ali tarafından onarım izni için, mahkemeye yapılan talep üzerine kurulan keşif heyetini gösterir arşiv belgesi. B.K.S. A-94, s. 36.

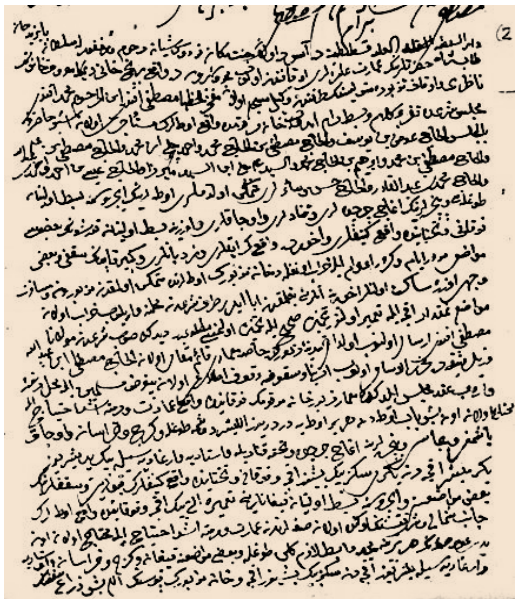

Belge 3. 13 Aralık 1677 tarihinde Pirinç Han'ında onarım öncesi yaklaşık maliyeti gösterir arşiv belgesi. B.K.S. B-140, s. 91

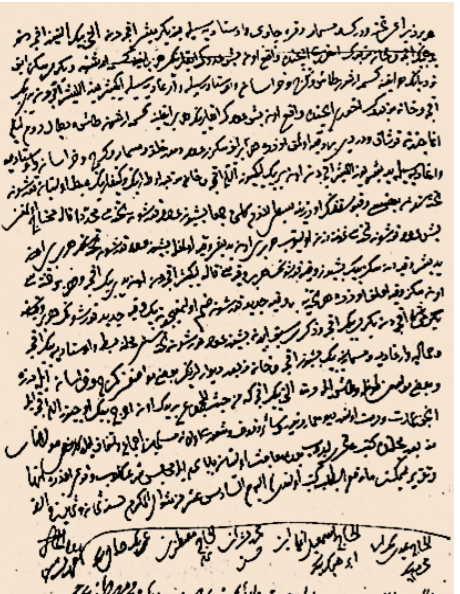

Belge 3. Devamı

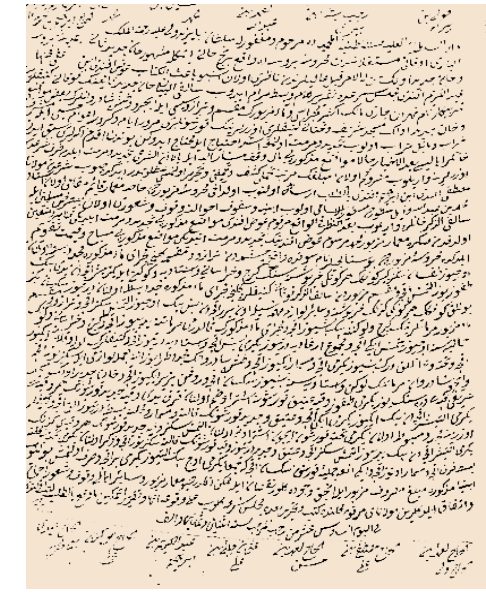

Belge 4. 19 Kasım 1671 tarihinde Pirinç Han'da, onarım sonrası tahammüli keşfi gösteren arşiv arşiv belgesi. B.K.S. B-116, s. 19. 


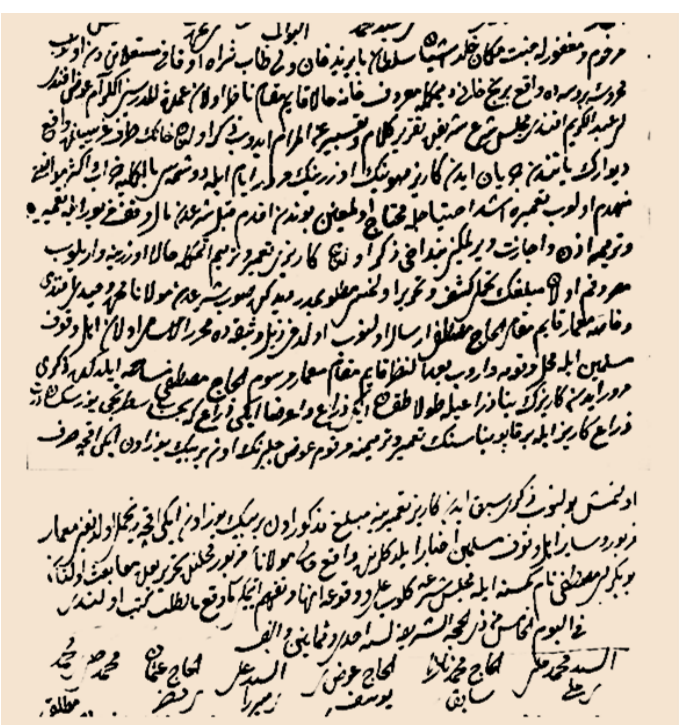

Belge 5. 28 Mart 1574 tarihinde Pirinç Han'ında, Onarım sonrası tahhammüli keşfi gösteren arşiv belgesi. B.K.S. B-90, s. 79

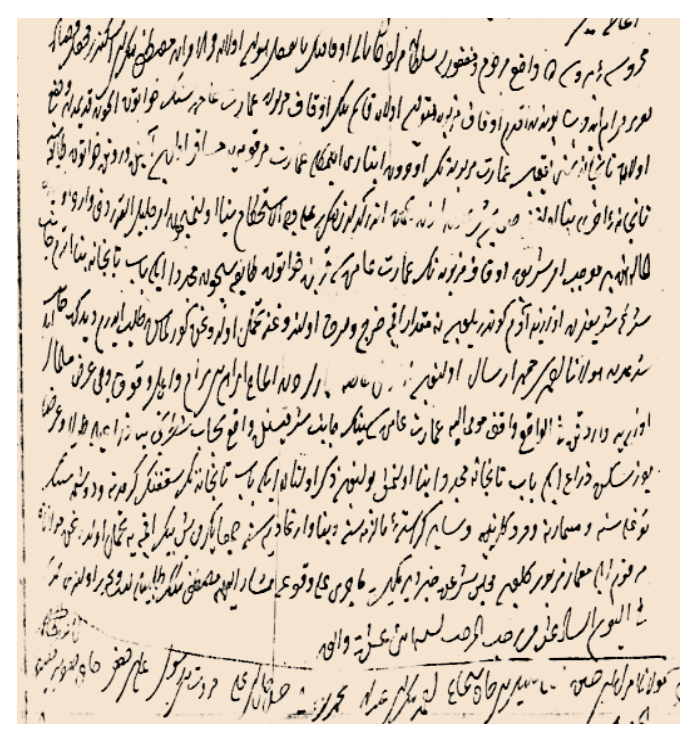

Belge 6. II. Murat vakfına ait marethanenin onarım sonrası çıkartılan tahammüli keşfine ait arşiv belgesi. B.K.S. A.155, s. 75/1.

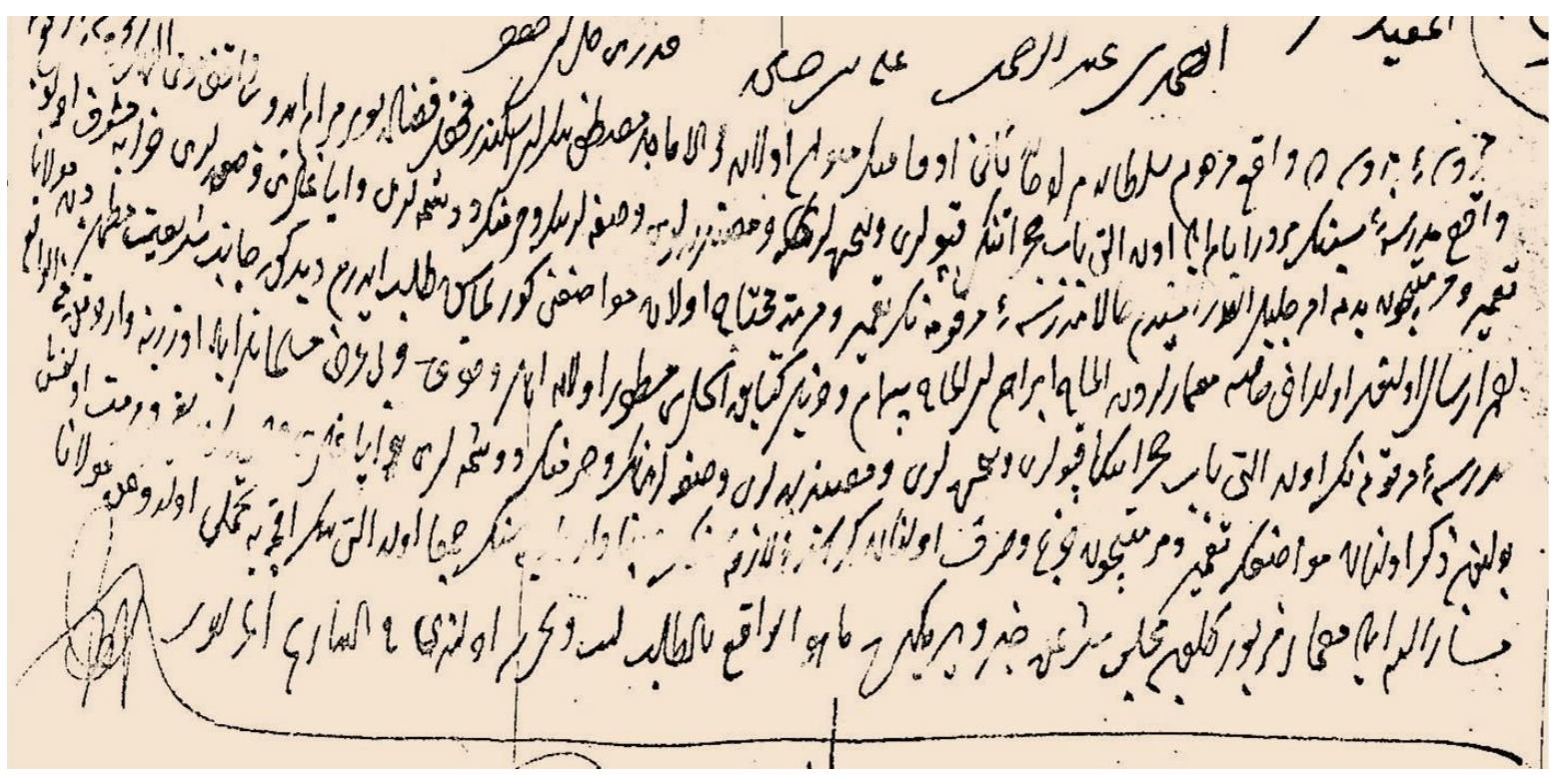

Belge 7. 1603 tarihinde, Sultan Murad Vakfı'nın mütevellisi Mustafa Bey tarafından, onarım sonrası yapılan talep üzerine, keşif heyetinin vakfa ait medresenin onarımı için çıkarttığı tahammüli keşfi gösteren arşiv belgesi. B.K.S. A.155, s. 75/2 